\title{
El programa iconográfico de la Casa de los Surtidores en Conimbriga
}

\author{
Guadalupe lópez Monteagudo *
}

La ciudad de Conimbriga, situada a $15 \mathrm{~km}$ de Coimbra muy cerca de Condeixa-a-Velha, ocupa un lugar privilegiado en una meseta que se extiende sobre un espolón calcáreo entre dos valles, estando el del Sur tallado por el rio dos Mouros.

La ocupación del sitio se remonta al siglo $v$ a. C., debiéndose la primera referencia literaria a Plinio (NH IV 11) y posteriormente en el Itinerario Antonino Conimbriga aparece citada como una etapa de la via que va de Olisipo (Lisboa) a Bracara Augusta (Braga), a 10 millas de Aeminium (Coimbra). En la segunda mitad del siglo $\vee$ d. C. el obispo Hidacio refiere los sucesos trágicos que acontecieron en la ciudad: la invasión de los suevos en el año 465 (FHA IX 83) y la destrucción en el 468 de las casas y de parte de las murallas (FHA IX 97) '. Sin embargo, Conimbriga sobrevivió a todos estos desastres y fue ocupada por los visigodos hasta su definitivo final con la invasión musulmana en el año 711.

Aunque las ruinas de Conimbriga se conocian desde mediados del siglo XVI, fue en la segunda mitad del XIX cuando comenzó a despertarse el interés por las mismas, iniciándose en 1899 las campañas de excavaciones. Fue V. Correia quien en 1912 localizó cerca de la muralla el primer hábitat, comenzando asi la prospección de la zona adyacente a la muralla Sur: Casa de los Surtidores, Casa de las Svásticas, Casa de los

- CSIC.

Tranoy, A., La Chronique d'Hydace, ed. trad. y coment., Coll. Sources Chretiennes, núms. 218-219, París 1975, II, 121 y 125. 
Esqueletos, puertas de la muralla, establecimiento comercial y Casa de Cantaber intramuros ${ }^{2}$. Las excavaciones franco-portuguesas llevadas a cabo entre 1964 y 1971 se centraron en el área monumental del Forum y de las Grandes Termas del Sur y pusieron al descubierto la insula del Vaso Fálico y la insula al Norte de las Termas ${ }^{3}$.

Sin lugar a dudas, de todas las casas de Conimbriga es la llamada de los Surtidores la más interesante por el repertorio iconográfico de los mosaicos que cubren sus estancias y peristilos ${ }^{4}$. Esta casa se halla emplazada a la derecha de la calzada que desde Sellium se dirigía a $A e-$ minium, atravesando la ciudad de Conimbriga de SE. a NO. La calle, de $4 \mathrm{~m}$ de ancho y porticada en su primer tramo, dejaba a su izquierda varias construcciones: Casa de las Svásticas, Casa de los Esqueletos, Casa de Cantaber, establecimiento comercial y termas del acueducto. Por el contrario, a la derecha y extramuros sólo se encuentra la Casa de los Surtidores, cuya planta de forma trapezoidal, con pequeños espacios triangulares, se adapta según sus excavadores al trazado de la calzada que posteriormente fue anexionada, junto a las fachadas de las casas contiguas por la izquierda, al recinto amurallado de los siglos $\| 1-\mathrm{IV}$ (Fig. 1).

Las excavaciones realizadas en la zona revelan que la Casa de los Surtidores fue construida en la primera mitad del siglo III sobre un edificio perteneciente al siglo I y del cual se conserva una cripta. Ocupa un espacio de $2.380 \mathrm{~m}^{2}$, de los que $569 \mathrm{~m}^{2}$ están cubiertos por mosaicos, distribuido en torno a un gran peristilo central al que se accede desde la fachada porticada situada al $O$. Esta mansión posee otros dos peristilos de menor tamaño y una piscina que rodea la cabecera del oecus-triclinium por su lado E., con la particularidad de tener embutidas en su pared ánforas que servian, al parecer, para recoger los peces cuando se procedía al vaciado y limpieza de la misma. Gran parte de la casa, es decir, la llamada zona noble, estaba pavimentada con mosaicos figurados y geométricos y sus paredes decoradas con pinturas y molduras de estuco.

2 Correia V., "A camada pré-romana da cidade”, Arq. Port. XXI, 1916, 252-264.

3 Alarcáo, J., Etienne R., Fouilles de Conimbriga, Paris 1974-1978, I-VII.

4 Agradezco a la Dirección del Museo Monográfico de Conimbriga las facilidades que me ha dado para estudiar y fotografiar estos mosaicos. Anteriormente habian sido publicados de forma concisa por M. BAIRRĀo OLEIRO, "Mosaïques romaines du Portugal", CMGR I, París 1965, 257 ss. Los temas mitológicos han sido recogido por BLAZOUEz, J. M., et alii, "La mitología en los mosaicos hispano-romanos", AEspA, 59, 1986, 101 ss.; los de caza por Blazquez, J. M., Lopez Monteagudo, G., "Iconografía de la vida cotidiana: temas de caza", Mosaicos fomanos. Estudios sobre iconografia (Actas del Homenaje in Memoriam de Alberto Balii), Guadalajara 1990, 59 ss. 


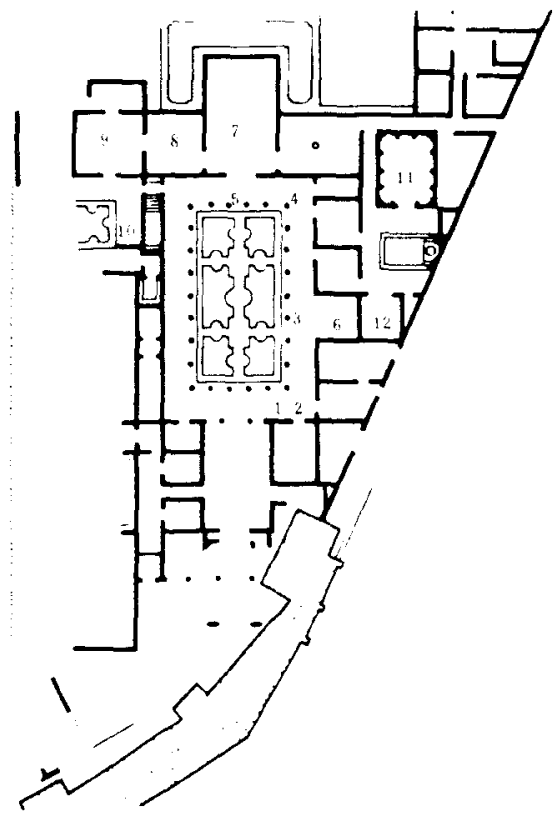

Fig. 1. Casa de los surtidores de Conimbriga. Distribución de los mosaicos sobre el plano de J. Alarcão-R. Etienne: 1. Mosaico del Laberinto. 2. Mosaico de Perseo y la Medusa. 3. Mosaico de Bellerofonte y la Quimera. 4. Mosaico del cazador. 5. Mosaico de Acteón. 6. Mosaico del centauro marino. 7. Mosaico del oecus-triclinium. 8. Mosaico del Auriga. 9. Mosaico con animales. 10. Mosaico del cazador. 11. Mosaico de cacería a caballo. 12. Mosaico de Sileno y el asno.

Los pavimentos han sufrido varias restauraciones como puede observarse fácilmente sobre todo en aquellos que decoran el peristilo principal, atestiguándose además en el oecus-triclinium la existencia de dos pavimentos superpuestos. No obstante, en todos ellos es posible apreciar una unidad no sólo de estilo sino también temática, que hace que la decoración de la Casa de los Surtidores de Conimbriga se haya concebido ajustándose a un programa iconográfico determinado.

La entrada principal de la casa se abre a un amplio peristilo de 25 $\times 17 \mathrm{~m}$ y 26 columnas, cuyo estanque está adornado con macizos de flores y surtidores de agua. Los cuatro lados se hallan pavimentados con mosaicos geométricos y figurados, siendo los emblemas de los ángulos y del centro de los corredores de forma circular, esquema que predomina en otros pavimentos de algunas de las habitaciones.

El corredor $O$. está adornado con un mosaico de tema mitológico: la representación del Laberinto en cuyo centro se encuentra la cabeza del 
Minotauro en forma casi de bucráneo (Fig. 2). Pertenece al tipo de representaciones calificadas por W. A. Daszewski como "simplificadas y simbólicas", que tanto pueden interpretarse como imágenes de un fuerte contenido alusivo o como simbolos profilácticos y apotropáicos ${ }^{5}$. Conimbriga ha proporcionado otro mosaico con el tema del Laberinto, que se guarda en el Museo Monográfico de la ciudad, pero esta vez más elaborado ya que alrededor del Laberinto aparecen las murallas y en el centro del mismo el busto del Minotauro visto con rasgos medio humanos medio animales. La leyenda de Teseo y el Minotauro, perteneciente al ciclo cretense, se describe en otros mosaicos hispanos: Pamplona, datado a mediados del siglo ॥; Córdoba, del siglo III; y Torre de Palma, de época constantiniana. En todos ellos, a diferencia de los pavimentos de Conimbriga, aparecen los dos personajes luchando ${ }^{6}$. Aquí se ha querido representar solamente el Laberinto como morada del Minotauro, al igual que ocurre en los mosaicos de Annaba (Argelia). Calvatone (Italia) y

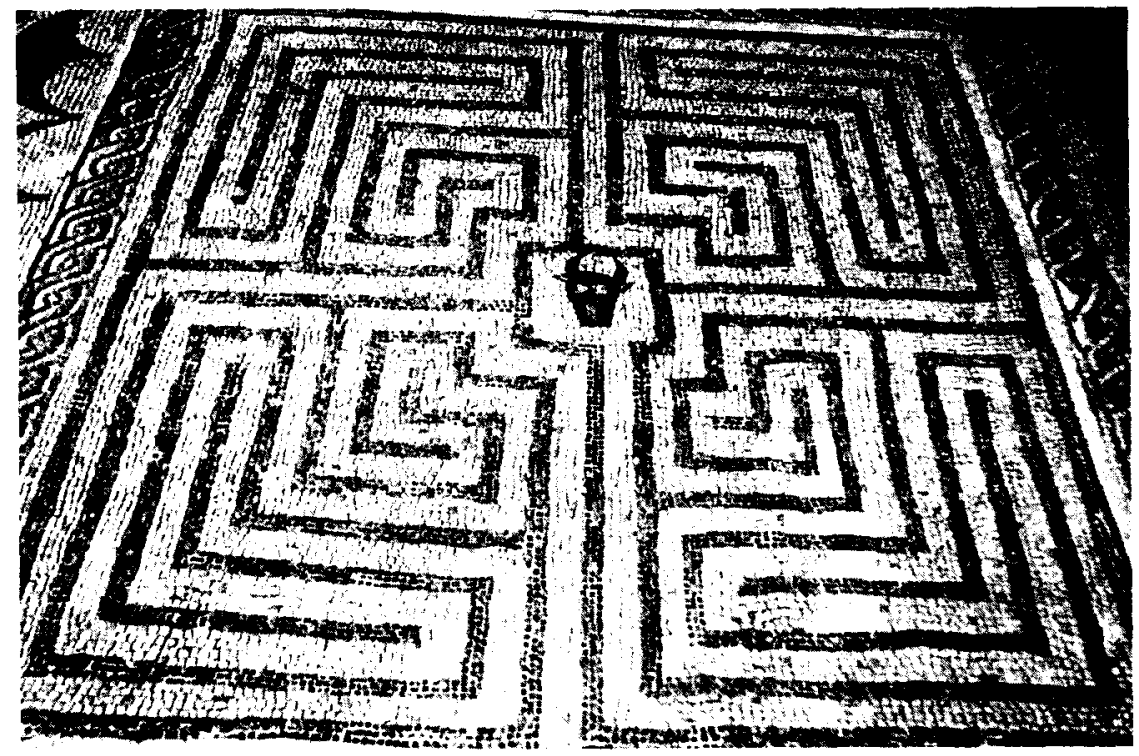

Fig. 2. Mosaico del Laberinto. (Foto G. L. M.).

5 Daszewski, W. A., Nea Paphos II. La mosaïque que Thésée, Varsovia 1977, 86 ss.

${ }^{6}$ Blazouez, J. M., Et alii. op. cit. (n. 4), 111. 
Stolac (Yugoslavia), en donde la reducción de los elementos iconográficos no excluye el conocimiento del mito ${ }^{7}$.

El pavimento del ángulo O.-SO. va decorado con la leyenda de Perseo y la Medusa (Fig. 3). La adaptación a la superficie se logra mediante un cuadrado que inscribe un círculo adornado con motivos florales, dentro del cual se halla inscrito a su vez otro cuadrado opuesto al primero, que encierra el emblema de forma circular. En él aparece Perseo desnudo, con alas en la cabeza y manto de color ocre prendido sobre el hombro derecho y cayendo por la espalda. En la mano derecha sostiene la cabeza de la Medusa, mientras que con la izquierda sujeta la harpè, utensilio utilizado para su dacapitación. A la derecha del héroe se ha representado al monstruo marino que iba a devorar a Andrómeda. Se han conjuntado en este mosaico dos episodios de la leyenda de Perseo, hijo de Zeus y Danae, obligado a llevarle al tirano Policdetes la cabeza de la Medusa Gorgona que, junto a sus hermanas, habitaba en los con-

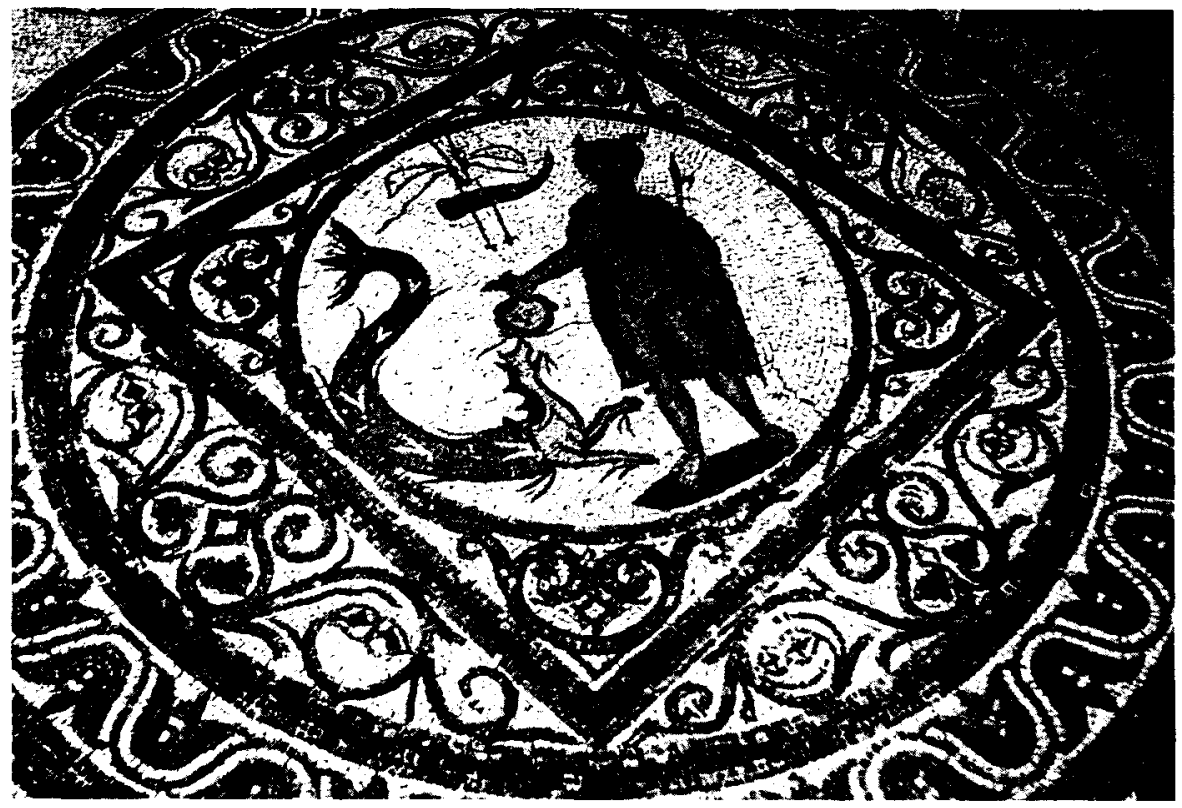

Fig. 3. Mosaico de Perseo y la Medusa. (Foto G. L. M.). 
fines occidentales de la tierra. Con la ayuda de Hermes y Atenea. Perseo dio muerte a la Medusa de cuyo cuello nacieron Pegaso y Chrisaor. Después de ofrecer la cabeza a Atenea, liberó a Andrómeda que espiaba encadenada a una roca las palabras proferidas por su madre Cassiopea de ser la más bella de las Nereidas. Esta segunda parte de la leyenda se halla representada en un pavimento de Tarragona, de estilo orientalizante según A. Balil, en donde aparece Perseo liberando a Andrómeda y al kethos moribundo a sus pies ${ }^{8}$. El paralelo más próximo a la escena de Conimbriga es una pintura pompeyana en donde el mito se reduce igualmente a la figura de Perseo con la cabeza de Medusa en su mano y al kethos ${ }^{9}$. En la parte alta del mosaico de la Casa de los Surtidores se ha representado una especie de cuerno, sujeto con un lazo que también aparece en el pavimento de Sileno de la misma casa. El resto de la decoración lo forman motivos fitomorfos que se repiten idénticos en los mosaicos del cazador y de Acteón, presentes en este mismo peristilo.

El centro del corredor $S$. ofrece otro mosaico de tema mitológico en muy mal estado de conservación, ya que se ha perdido la mitad del emblema de forma circular con el tema de Bellerofonte y la Quimera (Fig.4). Del cuadro solo se conserva ésta, corriendo hacia la izquierda, perseguida por Bellerofonte montado sobre el Pegaso, del que únicamente queda el hocico y las patas delanteras. La leyenda, que aparece ya en Homero (II. VI 155-205; 216-226), fue tratada repetidamente por varios poetas y literatos de la antigüedad (Hes. Theog. 319 ss; Pind. Od. XIII 87 ss; Istm. 7,44 ss.; Em. Esten. fragm.; Sof. Yob. fragm.; Hor. Od. VI 11,26 ss.; Paus. II 2. 3-5; 4.1-3; 27.2; etc.). Según el mito, Bellerofonte se refugia en Tirinto después de haber matado involuntariamente a $\mathrm{Be}$ lero, tirano de Corinto. En la corte del Rey Preto la esposa de éste, Estenobea o Antea, se enamora del héroe acusándole, al no ser correspondida, de intento de seducción. Bellerofonte es enviado por Preto a la corte del rey Yóbates de Licia quien, por encargo de aquel, intenta ocasionarle la muerte encargándole la misión de acabar con la Quimera. Pero Bellerofonte, con la ayuda del caballo alado Pegaso, hijo de Poseidón y de Medusa, vence a la Quimera, animal monstruoso mitad león, mitad dragón, con cabeza de cabra, que lanzaba llamas y que asolaba

"BaLIL, A., "ll mosaico "della Medusa" di Tarragona", Hommages à Marcel Renard III, Bruxelles 1969, 3 ss. La misma escena se representa en un mosaico de la Casa de Dionysos y Ariadna, en Antioquía, fechado en época severiana (cf. Levi, D., Antioch Mosaic Pavements, Princeton 1947, PI. XXIX b-c). El tema se repite en el pavimento norteafricano de Bulla Regia, de mediados del siglo II, (cf. Dunbabin, K. M. D., The Mosaics of Roman North Africa, Oxford 1978, PI. 9).

${ }^{9} L I M C \mathrm{I} / 2,779$, núm. 38. 


\section{El programa iconográfico de la Casa de los Surtidores en Conimbriga}

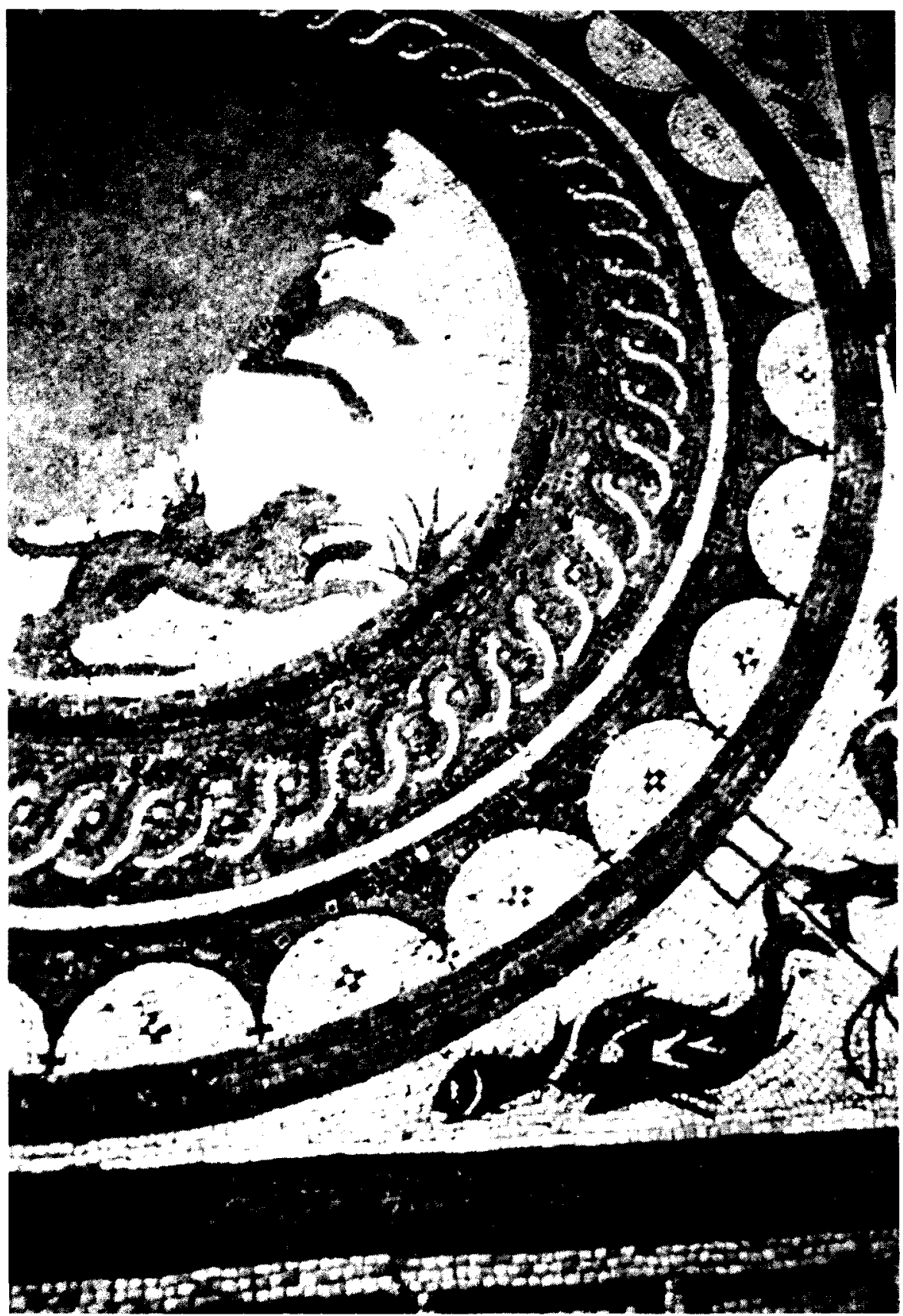

Fig. 4. Mosaico de Bellerofonte y la Quimera. (Foto G. L. M.). 
al pais robando los rebaños. La leyenda se representa en otros mosaicos hispanos con ligeras variantes: la lucha entre Bellerofonte y la Quimera aparece en Bell-Lloch y en Ucero; la persecución de la fiera, como en Conimbriga, se ofrece en el mosaico de Málaga; mientras que en el pavimento emeritense, fechado como los anteriores en el siglo Iv, Pegaso contempla a la fiera abatida mientras Bellerofonte descansa sobre una roca ${ }^{10}$. El resto de la decoración del mosaico de la Casa de los Surtidores lo forman un sogueado de dos cabos y una sucesión de arcos en blanco y negro que, rodeando concéntricamente al emblema, se inscriben en un cuadrado cuyos ángulos van adornados con un tridente entre dos delfines afrontados por la cola y dos pequeños peces. Idéntico motivo se vuelve a encontrar en el mosaico de Acteón, situado también en este peristilo, así como en un pavimento de la Casa del Tridente en Bulla Regia, en donde los delfines afrontados a un tridente aparecen acompañados de otros motivos simbólicos como el pavo real y las hederae ".

El ángulo S.-SE, va decorado con un esquema musivo idéntico al ángulo O.-SO., esto es, serie de cuadrados y círculos inscritos alternativamente, y con los mismos motivos fitomórficos (Fig. 5). En esta ocasión el emblema, también de forma circular, encierra no un episodio mitológico sino una escena de tipo realista: el regreso del cazador que acompañado de su perrc exhibe el trofeo de la caza, una liebre colgada de una bastón que apoya sobre el hombro izquierdo, mientras que en la mano derecha sostiene un pequeño cesto. El cazador responde al tipo iconográfico representado en otros mosaicos de la Casa de los Surtidores de Conimbriga: viste túnica corta de color amarillo-ocre, provista de mangas por encima del codo y adornada con clavi en tono oscuro; calza fasciae crurales, botas altas con protección en las rodillas, y camina precedido de su perro, tal vez un pointer, hacia la izquierda en un paisaje de matorrales de tonalidades ocres. La misma indumentaria se repite en los cazadores de la orla del mosaico hispano de Atalanta y Meleagro de Cardeñajimeno, que se fecha a fines del siglo IV ${ }^{12}$, asi como en los de la orla del pavimento de la Megalosypchia de Antioquia, de mediados del $v^{13}$. Un cazador vestido con túnica corta y llevando un cesto en la mano derecha y una liebre en la izquierda, como en el mosaico portugués,

10 Blazouez, J. M., et alii, op. cit. (n. 4), 106-107; Álvarez Martinez, J. M., Mosaicos romanos de Mérida. Nuevos hallazgos, Mérida 1990. núm. 17, lám. 49.

$"$ Dunbabin, K. M. D., op. cit., (n. 8), 164.

12 BLAzQuez, J. M., et alii, "Atalanta y Meleagro en un mosaico romano de Cardeñagimeno (Burgos, España)", Latomus 44, 1986, 557 ss., lám. XI.

${ }^{13}$ LEVI, D., op. cit. (n. 8), PI. LXXIX-d. 


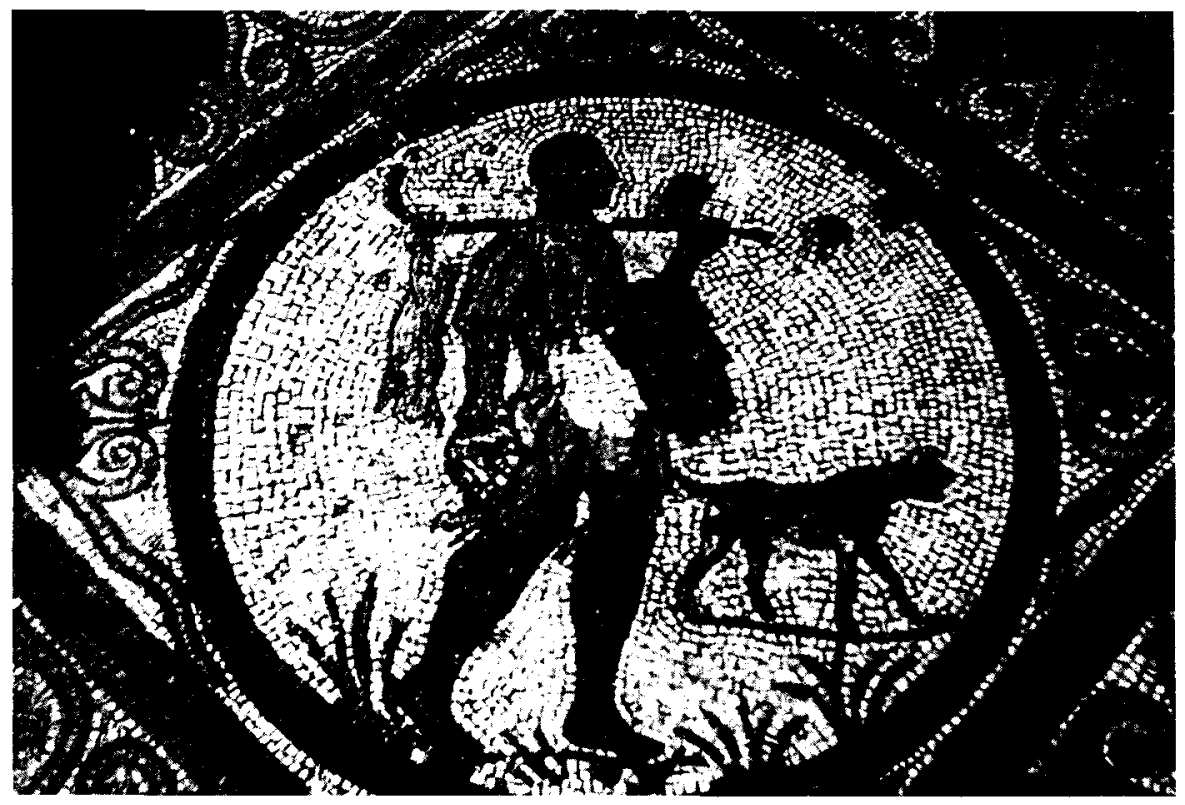

Fig. 5. Mosaico del cazador. (Foto G. L. M.)

aparece en el pavimento de la vendimia de Cherchel, datado a fines del siglo IV o a comienzos del $v^{14}$. Una presa colgada del palo que sostiene el cazador sobre el hombro se ve igualmente en el mosaico de la Caza de Althiburos, de fines del siglo III $^{15}$.

El centro del corredor $E$. presenta un pavimento de tema mitológico dentro de un esquema similar al de Bellerofonte y la Quimera (Fig. 6). La única diferencia estriba en que el emblema va dentro de un cuadrado opuesto al exterior, siendo la decoración de los dos círculos y de los ángulos exactamente igual al de áquel. Por su parte, los espacios resultantes de la inserción del cuadrado interior dentro de la circunferencia llevan una ornamentación fitomorfa del tipo de la documentada en los mosaicos del cazador y de Perseo. En el emblema se relata la leyenda de Acteón, a la que hacen referencia Hesiodo (Theog. 977), Eurípides (Bac. 337), Ovidio (Met. III 131 ss.), Apolodoro (Bibl. IV 4,4) y Pausanias ( 44,8$)$, entre otros autores. El mosaista ha escogido el momento del

${ }^{14}$ Dunbabin, K. M. D., op. cit. (n. 8), Pl. D.

15 Ennaifer, M., La cité d'Althiburos et l'édifice des Asclepeia, Tunis 1976, pl. CXLIII. 


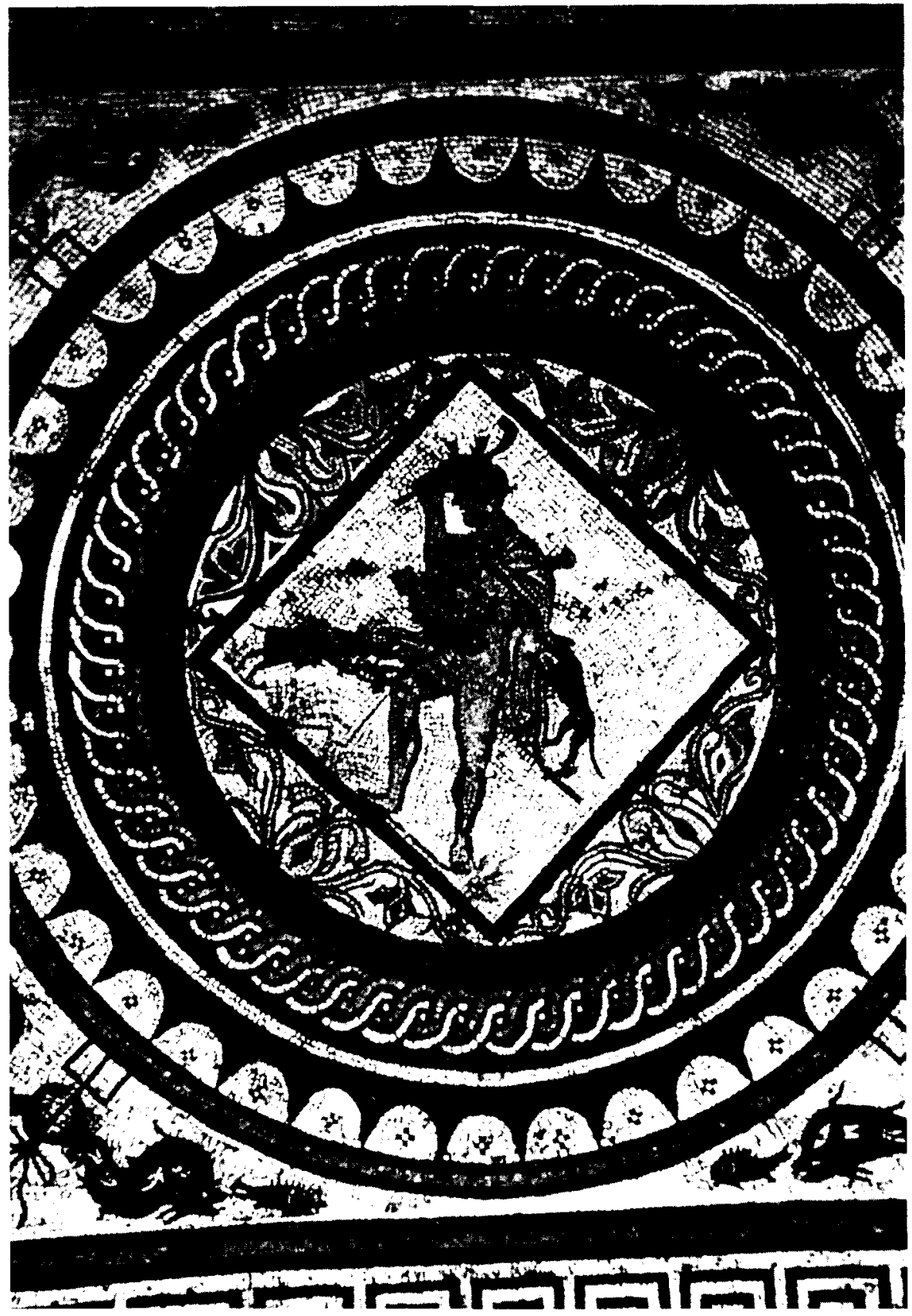

Fig. 6. Mosaico de Acteón. (Foto G. L. M.) 
mito en el que el héroe se convierte en ciervo y es devorado por sus perros, como castigo por haber sorprendido a Diana bañándose desnuda en el bosque. Acteón está representado de perfil y con cuernos de ciervo sobre su cabeza. Va completamente desnudo, excepto un manto de color amarillo-ocre que le cubre los hombros y cae por la espalda. En la mano derecha levanta el cayado con el que intenta defenderse de los perros que le atacan, uno de los cuales le muerde la pierna derecha y el otro el brazo izquierdo. Unos matorrales de tonos ocres indican el paisaje en donde se proyectan las sombras, de la misma forma que en el resto de los pavimentos figurados de la Casa de los Surtidores.

El primer episodio de la leyenda, Diana sorprendida por Acteón mientras se baña desnuda en la fuente acompañada por las ninfas, gozó de gran aceptación entre los musivarios, escultores y pintores de la antigüedad ${ }^{16}$. En la musivaria hispana el tema se halla representado en el mosaico de las Metamortosis de la villa toledana de Carranque, en el que Acteón aparece ya medio convertido en ciervo ${ }^{17}$. La segunda fase del mito en donde el héroe, con cabeza humana y cuernos de ciervo, es devorado por sus perros es la que se representa en el pavimento de Conimbriga y también en el de Cirencester, datado en el siglo II. El paralelo más próximo para el emblema portugués se encuentra en un candelabro, de mediados del siglo II, que se guarda en el Museo Arqueológico Nacional de Madrid. En todas estas representaciones Acteón se defiende con el pedum. ${ }^{18}$

En el centro del corredor S., a la altura del mosaico de Bellerofonte y la Quimera, se abre una habitación de $3 \times 3 \mathrm{~m}$, identificada como despacho o escritorio, decorada con un curioso pavimento de tema marino (Fig. 7). Rodeado de una composición de tipo geométrico y enmarcado por una orla de sogueado, se extiende un tapiz de forma cuadrada relleno de coronas florales tangentes cuyo interior encierra alternativamente delfines y dragones marinos. 48 grullas ocupan los espacios triangulares formados por la intersección de los círculos. El centro de este campo musivo va decorado con un cuadro en el que se ofrece la figura de un centauro marino hacia la derecha, sosteniendo un vexillum en su mano derecha y un delfín en la izquierda. En la parte inferior se han

${ }^{16}$ LIMC I/1, 454-469. El tema aparece en los mosaicos de Volubilis, Shahba-Philipoppolis y Thina, fechados a 10 largo del siglo III, y de Timgad, ya del siglo IV-V, entre otros (ct. Dunbabin, K. M. D., op. cit (n. 8). PI. XIII.

17 ARCE, J., "Mosaico de "Las Metamorfosis" de Carranque (Toledo)", MM 27, 1986 365 ss.

${ }^{18}$ LIMC $1 / 1,460-461$, núms. 66 y 73. 


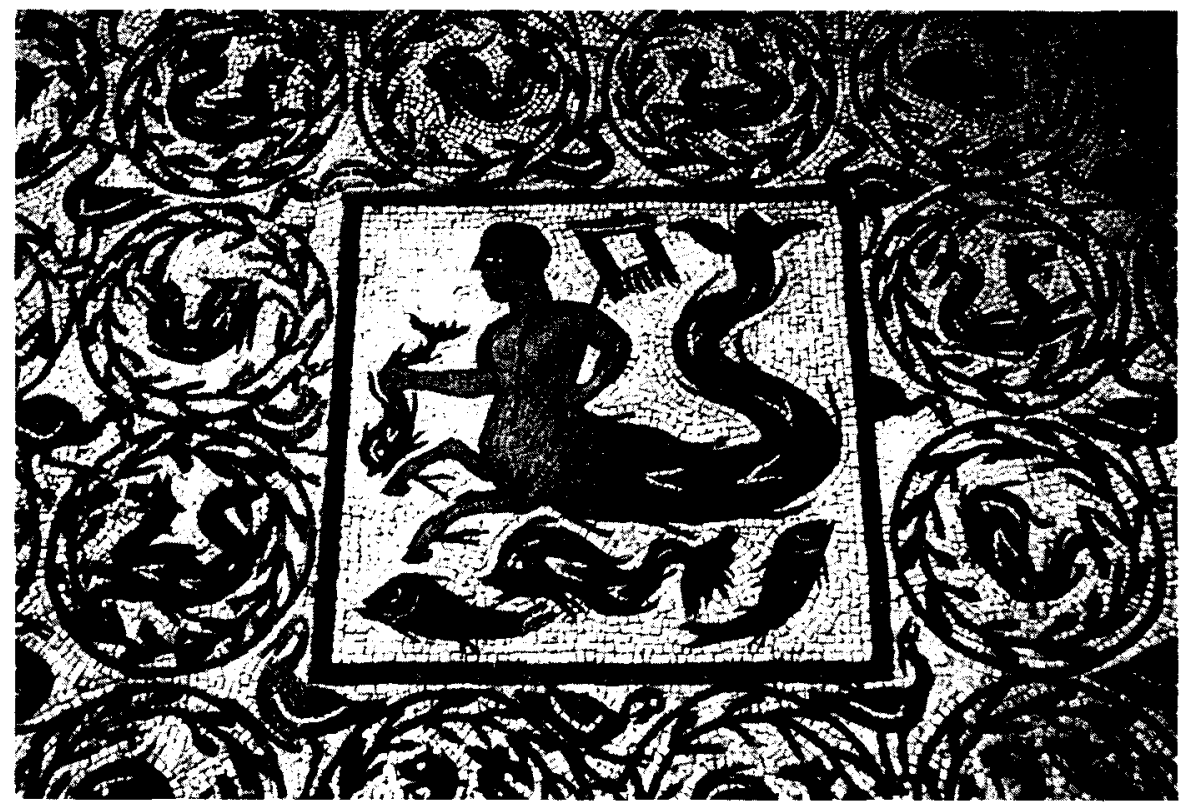

Fig. 7. Mosaico con centauro marino (Foto G. L. M).

representado otro delfín de mayor tamaño y dos peces. Por sus rasgos faciales el centauro pertenece al mismo tipo iconográfico que los cazadores de otros mosaicos de la Casa de los Surtidores. En la musivaria hispano-romana se documentan centauros marinos integrantes del thiasos y solo en dos ocasiones aparecen individualizados y como tema principal del emblema: éste de Conimbriga y el de Sesamón, aunque aquí se ha representado el tritón en busto con una cronología a finales de los Antoninos o comienzos de los Severos ${ }^{19}$. Como en el caso del mosaico del Laberinto, se trata de una representación simplificada del thiasos marino, característica que se observa frecuentemente en otros pavimentos de Conimbriga ${ }^{20}$.

La decoración de coronas florales tangentes se repite en el pavimento que cubre el suelo del oecus-triclinium (Fig. 8). Esta habitación, situada en el eje de la puerta principal de la casa con acceso desde el

19 Torres, M., "Iconografía marina", Actas del Homenaje in Memoriam de Alberto Balit, Guadalajara 1990, 124-125.

zo Bairráo Oleiro, M., op cit. (n. 4). 260. 


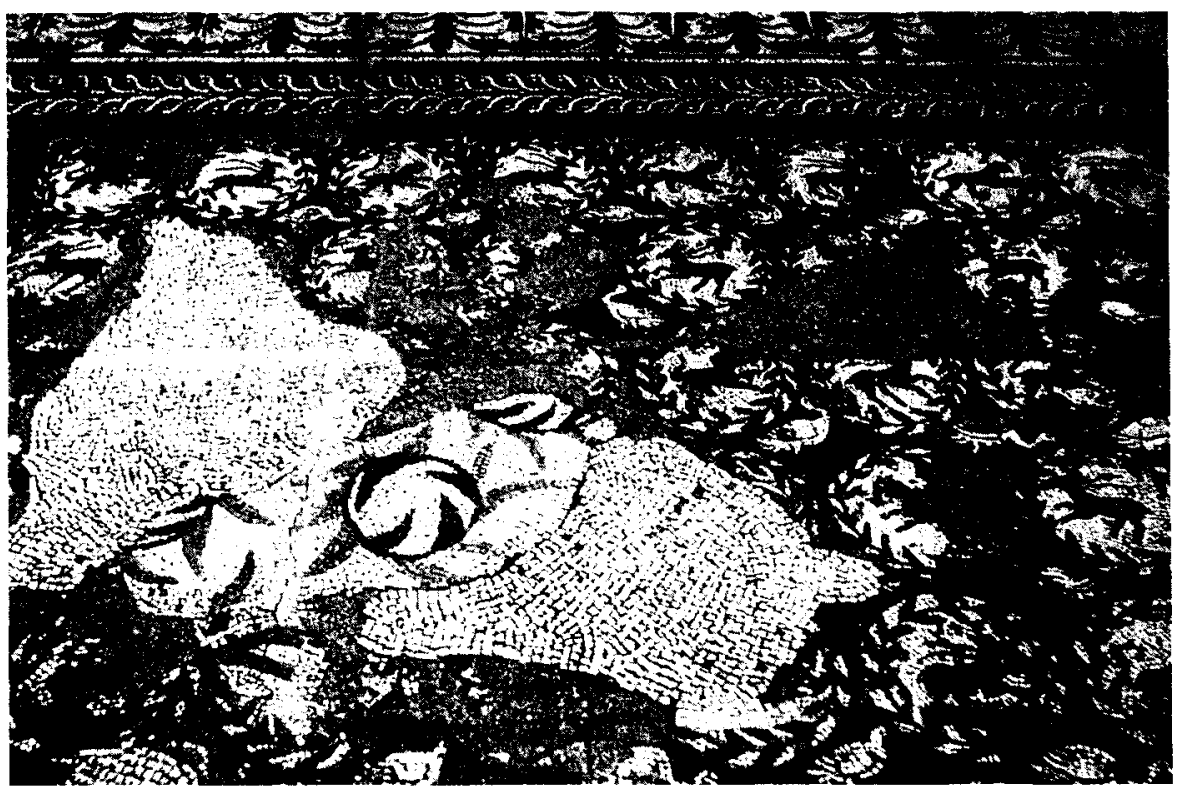

Fig. 8. Mosaico del oecus-triclinium con decoración de cabras y panteras. (Foto G. L. M.).

centro del corredor $E$. del gran peristilo, tiene unas dimensiones de $7,6 \times 12 \mathrm{~m}$ y está rodeada por un estanque. El pavimento primitivo, sobre el que se colocó en fecha posterior otro de inferior calidad, forma un tapiz de círculos tangentes enmarcado por un trenzado de dos cabos y una greca de motivos fitomorfos. El interior de los círculos va decorado con coronas florales que encierran en una parte cabras y panteras y en la otra aves y kantharoi alternativamente, siendo pájaros también los que decoran los espacios entre los círculos, motivos todos de clara connotación dionisiaca (Fig. 9).

A través de una puerta situada en el muro $\mathrm{S}$. del oecus-triclinium se accede a la zona de servicio. En el lado contrario otra puerta da paso a una habitación de $6 \times 6 \mathrm{~m}$ pavimentada con el mosaico más interesante de toda la casa (Fig. 10). El campo musivo va decorado con motivos geométricos, cuadrados, círculos y triángulos que forman series de octógonos secantes en color azul y ocre sobre fondo blanco. Grandes desperfectos, sobre todo en la parte central, afectan de manera importante a la escena figurada. Ésta, que se desarrolla en un cuadrado de $2,60 \times 2,60 \mathrm{~m}$, aparece dividida en varios compartimentos mediante la 


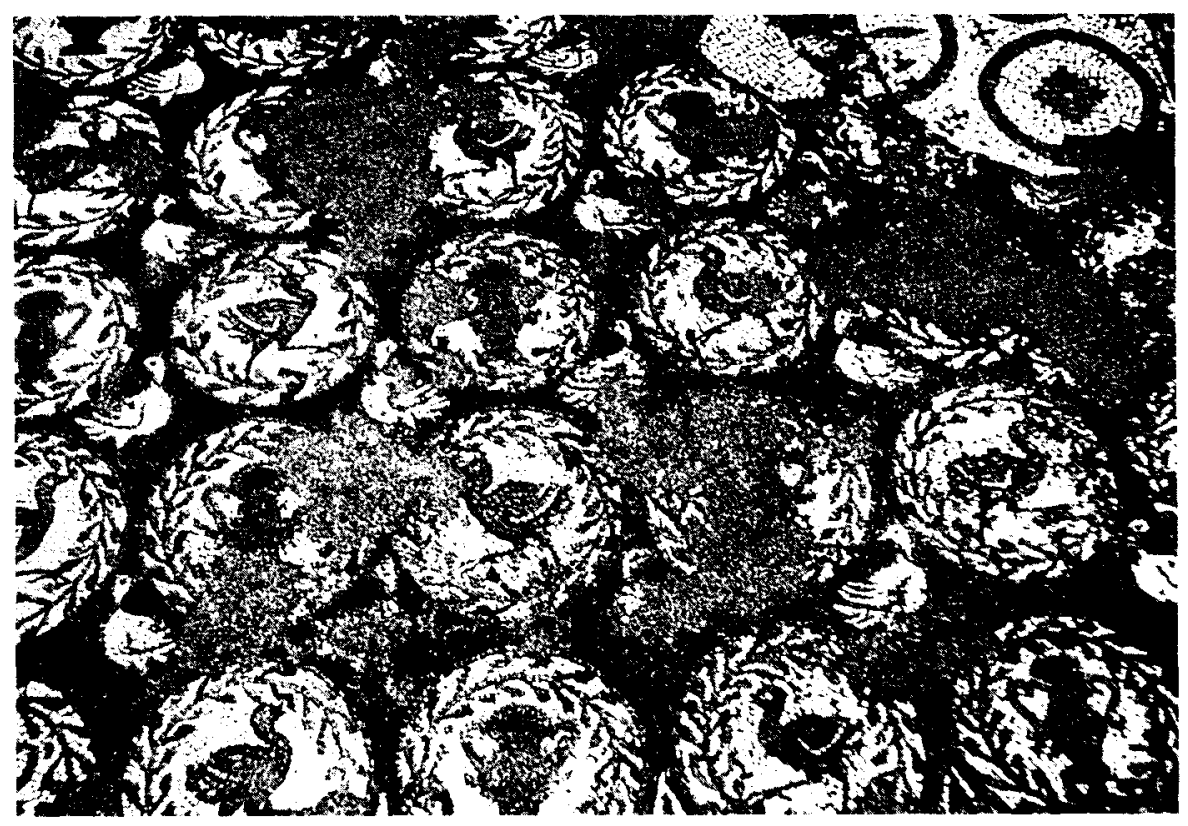

Fig. 9. Mosaico del oecus-triclinium con decoración de aves y kantharoi.

(Foto G. L. M.)

intersección de cuatro cenefas de pseudo-guiloches en escuadras superpuestas que, al cruzarse, determinan cuatro cuadrados y cuatro rectángulos en cuyo interior se inscribe un círculo de 1,30 m de diámetro.

En los paneles cuadrangulares se han representado los bustos de las Estaciones. La Primavera, de la que solo se conserva la mitad izquierda, va vestida con túnica a franjas amarillas y ocres provista de mangas y su cabello, que cae en grandes rizos sobre los hombros, se adorna con una especie de corona floral (Fig. 11). El Verano se representa mediante un busto desnudo, de carnaciones rosadas, con hoz sobre el hombro derecho, collar de dos vueltas y tocado de espigas sobre la cabeza; el cabello, abundante y ondulado, cae sobre los hombros como en la figura anterior (Fig. 12). El Otoño, en bastante buen estado de conservación, se cubre con túnica de color amarillo prendida en los hombros y adorna su cabeza con corona de pámpanos y uvas (Fig. 13). Finalmente, la figura del Invierno es una dama de rostro melancólico, vestida con pesada túnica de color oscuro, que cubre su cabeza con manto del mismo tono. Es la mejor conservada de todas las Estaciones (Fig. 14). 


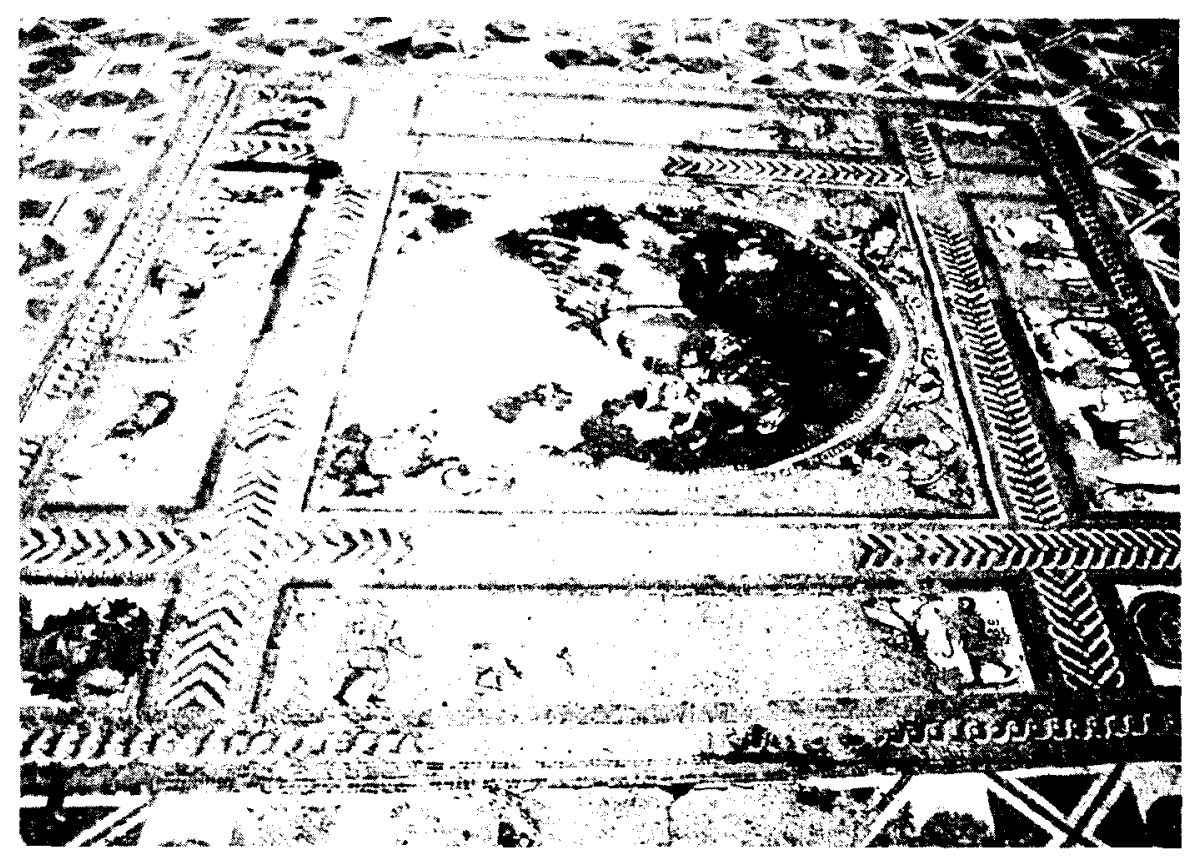

Fig. 10. Mosaico del Auriga. (Foto G. L. M.).

En los compartimentos rectangulares se ha representado una escena cinegética en estilo narrativo continuo, dividida en cuatro episodios que de alguna manera paracen guardar cierta relación con los periodos estacionales. Así, el cuadro que precede a la Primavera representa la partida de dos cazadores acompañados de sus caballos y perros, en un frondoso paisaje integrado por matorrales y tres árboles que enmarcan a cada uno de los dos grupos que componen la escena (Fig. 15). Los cazadores son hombres jóvenes, de cabello y barba de color oscuro, que caminan llevando de las bridas a sus cabalgaduras y por las correas a sus perros, unos galgos inquietos por correr hacia la presa. Visten túnicas cortas de color amarillo y ocre, adornadas con clavi y provistas de mangas por encima del codo. Calzan fasciae crurales. La escena representa el comienzo o la preparación de una cacería con redes que en este episodio son transportadas a lomos de los caballos. El cuadro anterior a la figura del Verano, aunque muy destrozado, deja ver sin embargo el episodio siguiente en el que el cazador batea, al parecer, a un animal a través de la fornido tendida entre los árboles (Fig. 16). Tanto los matorrales, como la copa extendida del árbol para proporcionar el máximo de sombra y las ramas colgadas de la cuerda, ofrecen todo el aspecto de una vegetación 


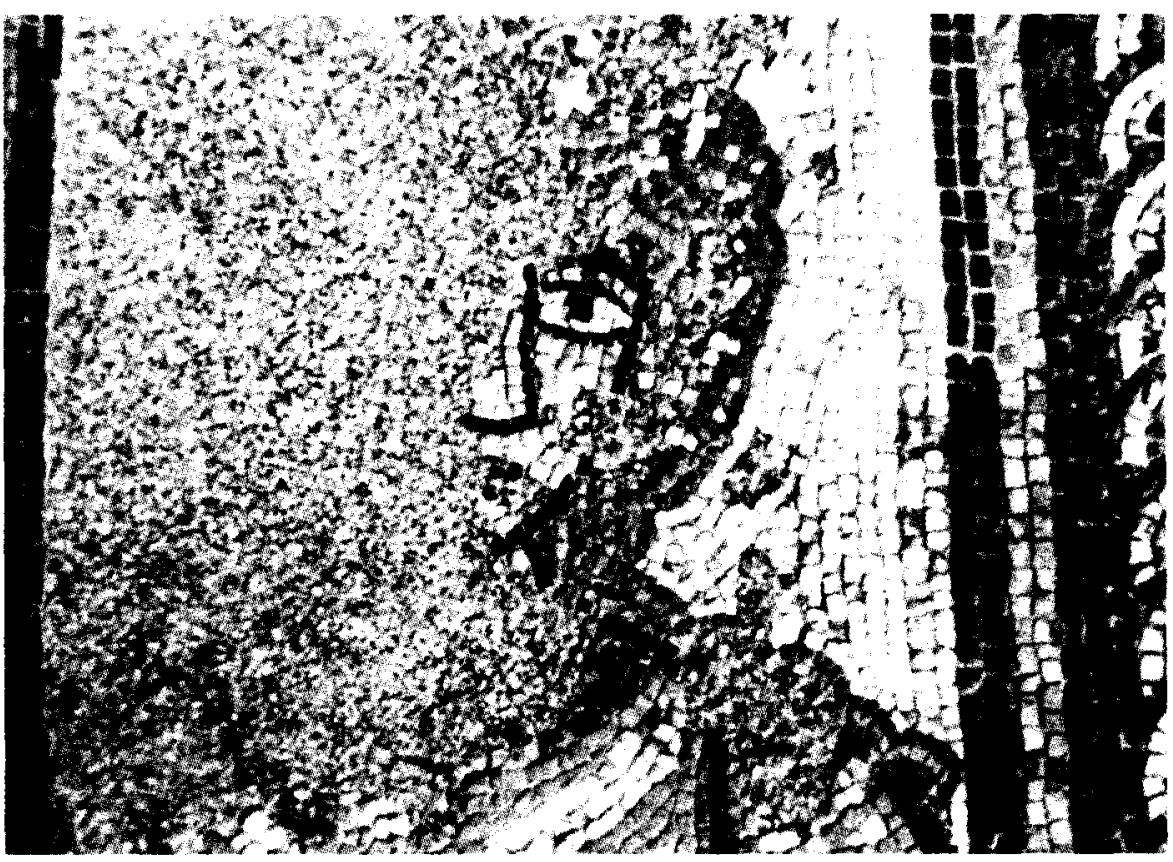

Fig. 11. Mosaico del Auriga. Representación de la Primavera. (Foto G. L. M.).

estival. La escena que continúa y que precede a la figura del Otoño es la mejor conservada de todas. Representa la caceria del jabali con perro en un paisaje típicamente otoñal (Fig. 17). Los cazadores visten de la misma forma que los de las escenas precedentes, pero sus túnicas ya no son de color amarillo, sino rosadas. El primero, de nombre SEVERVS, camina llevando de la correa a un perro que persigue con furia a la presa. El segundo, cuyo nombre parece ser ERE[-]IATVS ${ }^{21}$, porta sobre su hombro izquierdo las estacas para sujetar la redes, mientras que en la mano derecha empuña el venabulum (Fig. 18). El episodio final, que se cierra con la figura del Invierno, ofrece una cacería con red, de la que tantos paralelos existen en mosaicos, relieves, sarcófagos, vidrios, etc. ${ }^{22}$. La escena, muy destrozada en su parte central, deja ver solamente las figuras de los extremos. A la izquierda se ha representado a un hombre

21 Alarcāo, J., Portugal Romano, Lisboa 1974, 195, lee SPECTATVS.

22 Blaquez, J. M., Lopez Monteagudo, G., op. cit. (n. 4), 74-75. No lejos de Conimbriga, en el Museo Nacional de Arte Romano de Mérida se guarda un relieve en donde se representa una caceria de ciervos contra una red. 


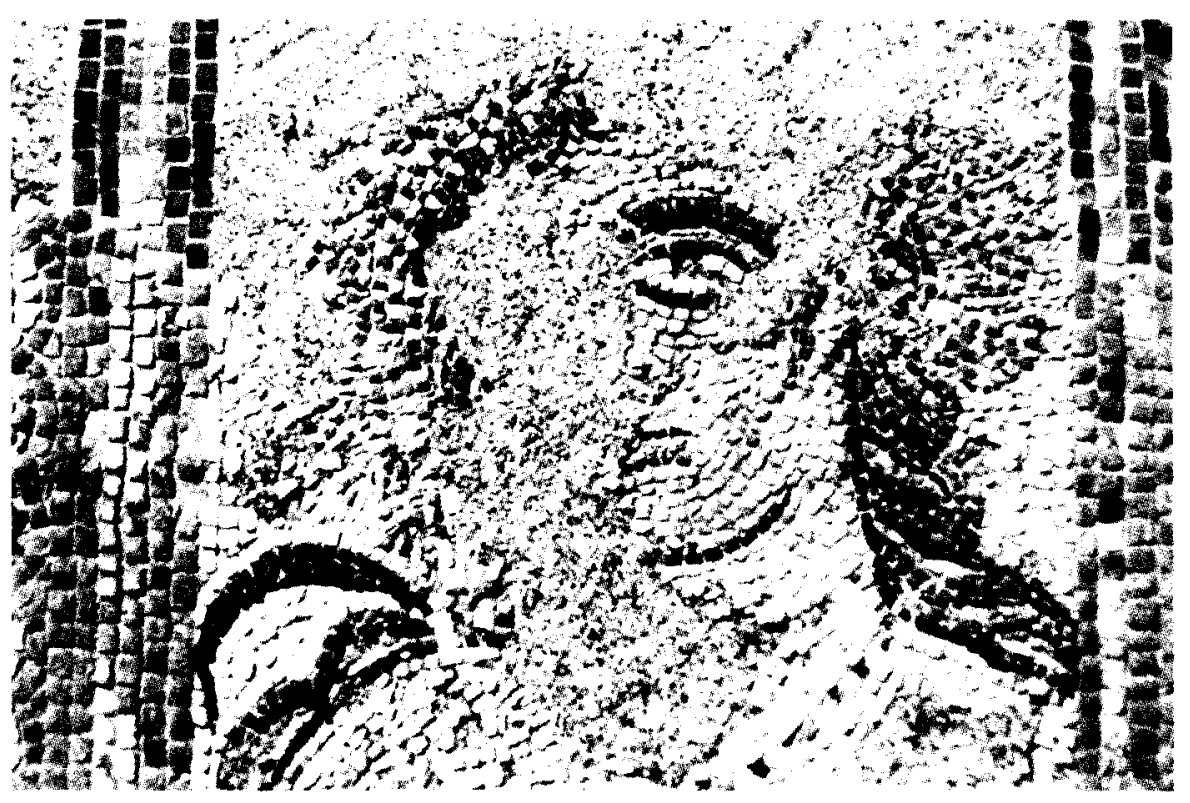

Fig. 12. Mosaico del Auriga. Representación del Verano. (Foto G. L. M.).

de edad madura, con el cabello y la barba de color canoso; viste túnica corta, moteada en amarillo y ocre, adornada con clavi y con mangas sobre los codos; calza no fasciae crurales como los otros cazadores, sino unas pequeñas botas bajas (caligae). Lleva de la cuerda, cuyo extremo sujeta con la mano derecha, a un perro del que solo se ha conservado parte de la mitad posterior, que debia de azuzar contra la red extendida en el extremo opuesto a una 0 varias presas que se han perdido (Fig. 19). El personaje de la derecha, cuyo nombre es CVME[---] ó CLIME[--- $]^{23}$, viste túnica corta de color amarillo, calza fasciae crurales y lleva un pedum o cayado en su mano izquierda (Fig. 20). Se trata del final de la cacería, alusión junto al cazador viejo de la finalización del año y símbolo del invierno.

Esta secuencia cinegética pertenece al tipo de representación de caza realista de la que la musivaria hispana ha dado solamente otro ejemplo. Se trata del mosaico parietal con escena de caceria que, en

\footnotetext{
23 AláRCĀo, J., op. cit. (n. 21), 195, lee CALIMERVS.
} 


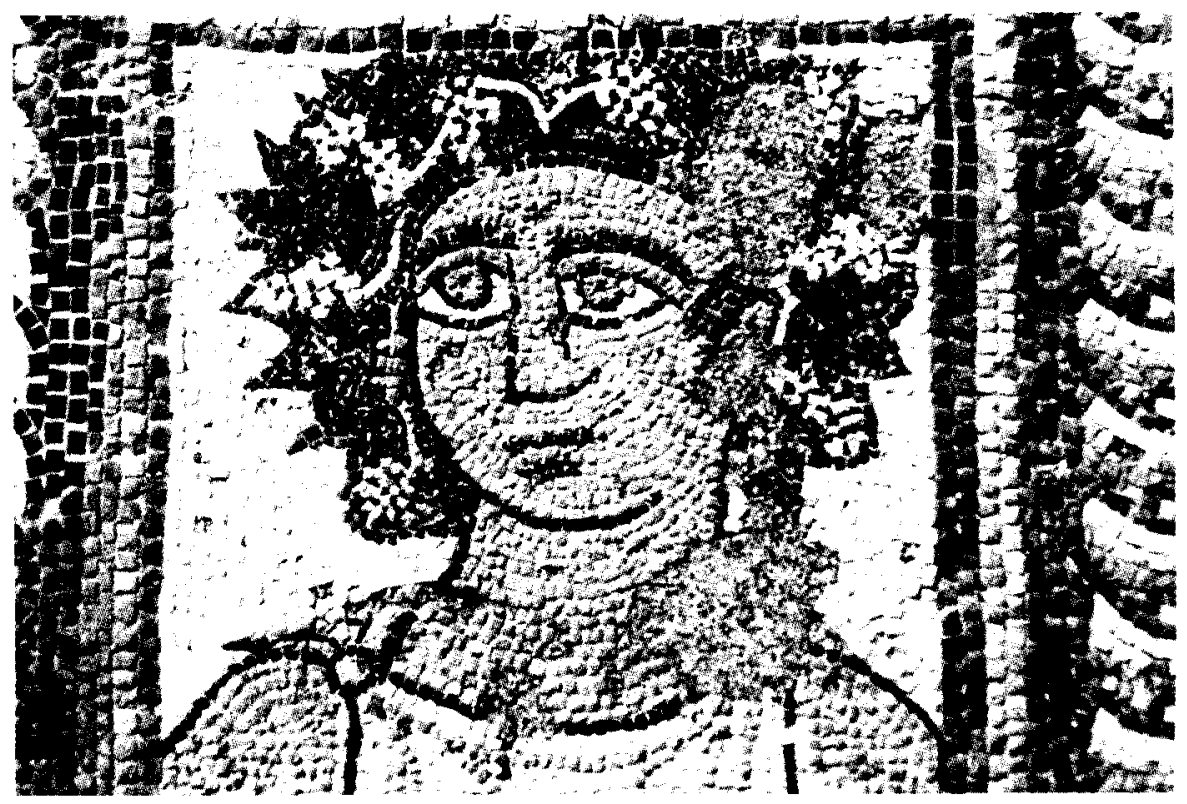

Fig. 13. Mosaico del Auriga. Representación del Otoño. (Foto G. L. M.).

forma de friso continuo, adorna la cúpula del mausoleo de Centcelles, datado a mediados del siglo $\mathrm{IV}^{24}$. Ambos pavimentos ofrecen varias particularidades comunes, como son las redes llevadas a lomos de las caballerías, los perros sujetos por las correas, el empleo de la fornido y las estacas portadas a hombros de personajes que en el mosaico de Centcelles podrian identificarse con servidores o criados. Algunos paralelos se encuentran en mosaicos de fuera de Hispania, como las redes transportadas a lomos de mulas en el mosaico con la oferta de la grulla a Apolo y Diana de Kartago-Khereddine, fechado en $390-411^{25}$; o los perros llevados por las correas en el mosaico de la caza del jabalí de Cartago, ca. 210-230 ${ }^{26}$, en el de la caza de la liebre de El Djem, datada a mediados del siglo $1{ }^{27}$, en el de Althiburos, de $280-290^{28}$, o también en los mosai-

\footnotetext{
24 Schlunk, H., Die Mosaikkuppel von Centcelles, MB 13, Mainz 1988, passim.

25 Dunbabin, K.M.D., op. cit. (n. 8), PI. 35

26 Ibidem, PI. 21

27 Ibidem, PI. 22

28 EnNaífer M., op. cit. (n. 15), pl. CXLIII.
} 


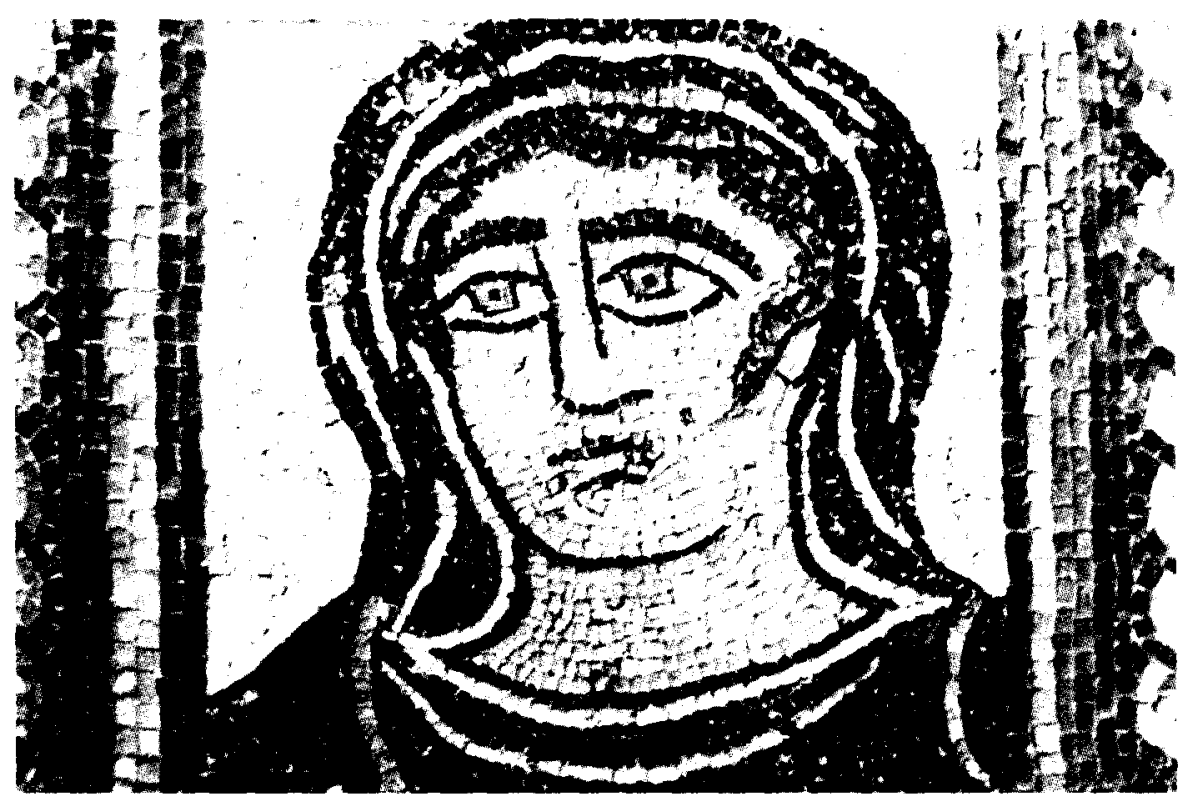

Fig. 14. Mosaico del Auriga. Representación del Invierno. (Foto G. L. M.).

cos de caza del Esquilino ${ }^{29}$ y de Piazza Armerina ${ }^{30}$, de comienzos del siglo IV, y en el del Triclinio de Apamea, de fines del mismo siglo ${ }^{31}$, por citar solo unos ejemplos. La indumentaria de los cazadores, que es idéntica en todos los mosaicos de la Casa de los Surtidores de Conimbriga: túnica corta adornada con clavi y fasciae crurales, tiene un paralelo muy próximo en los cazadores llevando redes al hombro o cazando ciervos con red del mosaico de la Caza de Utica, fechado en la segunda mitad del siglo IV ${ }^{32}$. Cazadores acompañados de sus nombres, como en el pavimento portugués, se documentan asimismo en el mosaico de la caza de osos con red del Museo de Malibú, ca. 220-250, y en el de Althiburos, de $280-290^{33}$. Esta moda de identificar a las figuras por sus nombres

${ }^{29}$ LaVIN, I., The Hungting Mosaics of Antioch and their Sources, DOP 17, 1963, 258, fig. 123 .

${ }^{30}$ Carandini A., et alii, Filosofiana. La villa de Piazza Armerina, Palermo 1982, fig. 97

${ }^{31}$ BaLtY, J., "La grande mosaïque de chasse des Musées Royaux d'Art et d'Histoire et sa datation", Colloque Apamée de Syrie, Bruxelles 1969, 131 ss.

32 Alexander M., Ennaifer M., Corpus des Mosaiques de Tunisie, 1/1, Tunis 1973, 74 75, núm. 85. pl. 34 .

${ }^{33}$ Ball, D., "A Bear Hunt Mosaic». J. P. Getty Mus 12, 1984, 123 ss., figs. 1a y 1b. 


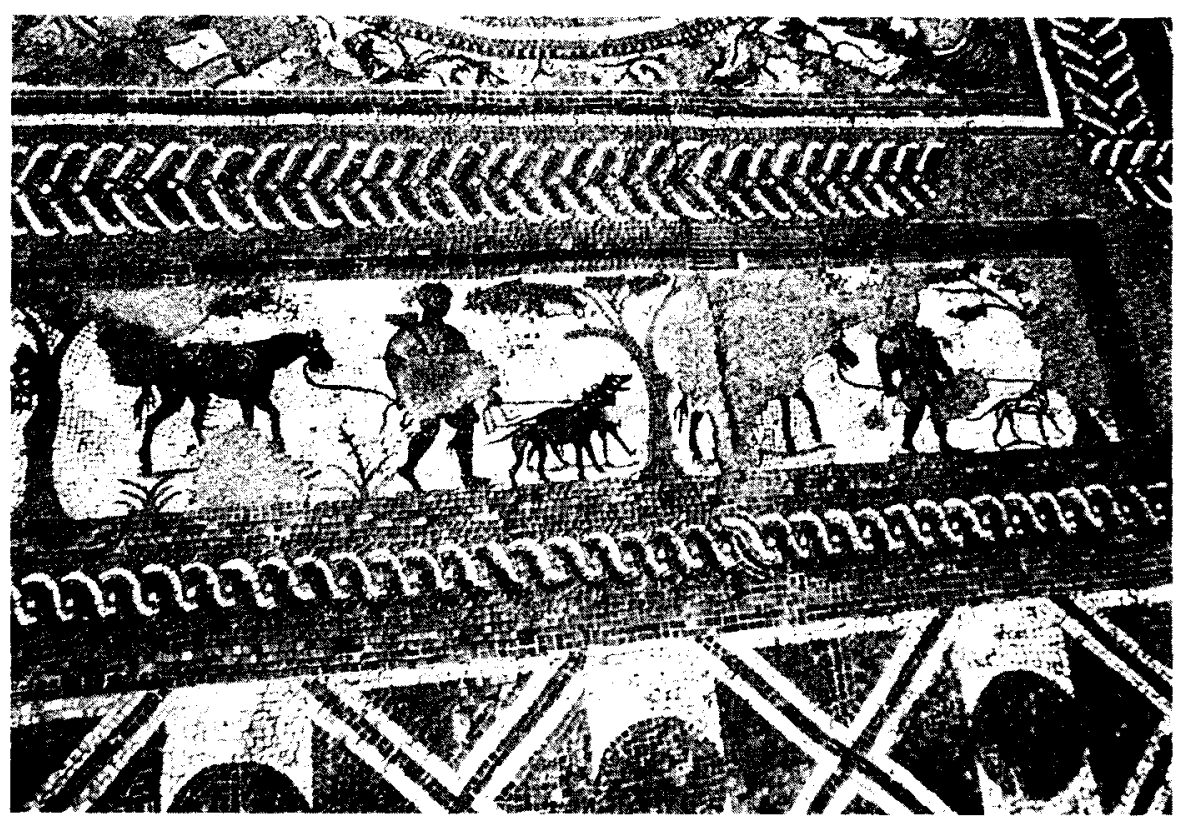

Fig. 15 Mosaico del Auriga. Escena de caza. (Foto G. L. M.).

aparece en la musivaria norteafricana a lo largo del siglo III y supone, según K.M.D. Dunbabin, un incremento del control del propietario sobre el contenido de los pavimentos que decoraban su casa ${ }^{34}$.

El cuadrado central, de $1,50 \times 1,50 \mathrm{~m}$, lleva en los espacios que deja libres el círculo en él inscrito una decoración fitomorfa formada por roleos vegetales, que surgen de los cuatro ángulos y que sostienen cuatro figuras femeninas de carácter alegórico (Fig. 21). Estas figuras, muy próximas iconográficamente a las representaciones del Verano y de la Primavera, visten túnica de color amarillo, peinan el cabello en aladares a ambos lados del rostro y levantan sus brazos asiendo con las manos la vegetación de la que ellas mismas parecen formar parte. Podrian identificarse con las horae, divinidades dispensadoras de riqueza y de abundancia, cuya función es hacer crecer las ramas y que se abran los frutos según el ritmo de las estaciones ${ }^{35}$. Sus brazos levantados parecen sostener, al mismo tiempo, el círculo central, símbolo de la bóveda celeste,

${ }^{34}$ Dunbabin, K.M.D., op. cit. (n. 8), 46 ss.

${ }^{35}$ Vernant, J. P., Mito y pensamiento en la Grecia Antigua, Barcelona 1985, 254-255. 


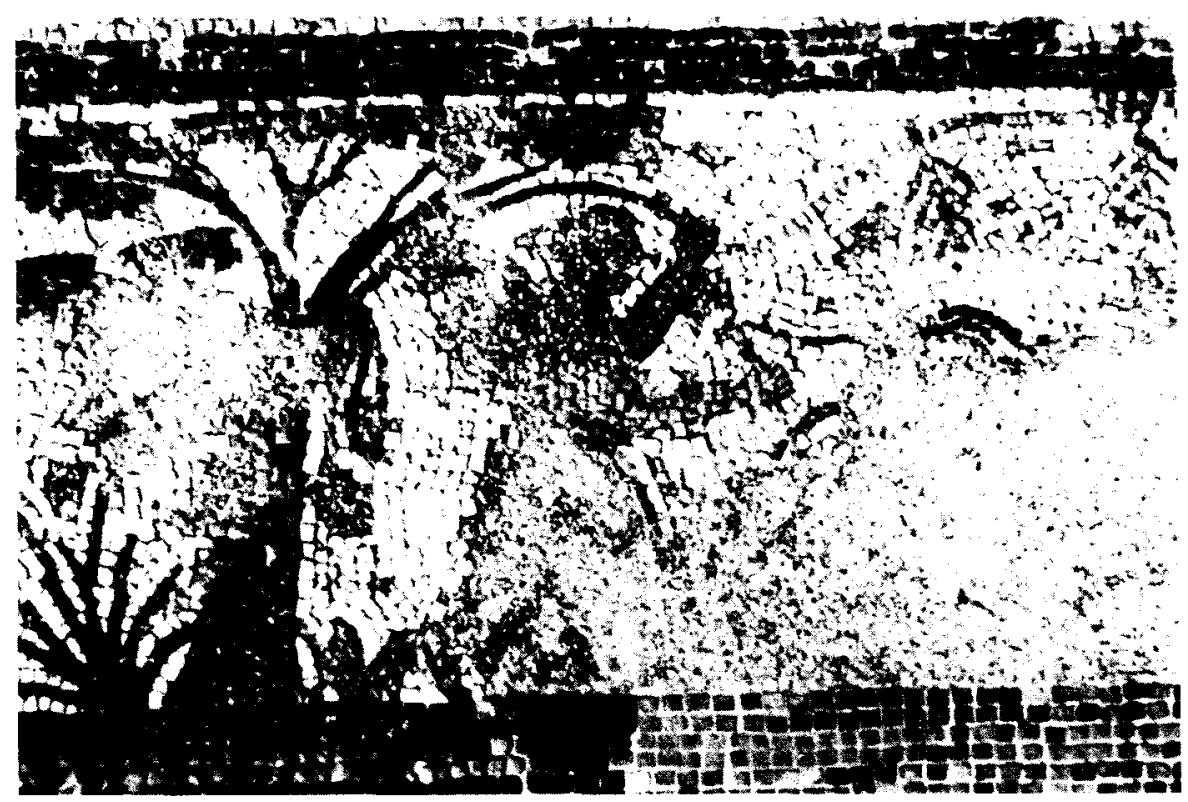

Fig. 16 Mosaico del Auriga. Escena de caza. (Foto G. L. M.).

presidido por la figura del auriga victorioso sobre un fondo azul intenso cuajado de estrellas ocres y amarillas (Fig. 22). El auriga, representado en tres cuartos, conduce con la mano izquierda un carro tirado por cuatro corceles blancos de crines doradas, vistos de perfil, que galopan briosamente hacia la izquierda, esto es, en dirección al peristilo principal de la casa. Viste túnica blanca adornada con clavi y pequeñas cruces de color ocre y amarillo, que ciñe mediante un ancho cinturón de tonos dorados. El cabello es rubio y ondulado y las carnaciones rosadas. En sus manos sostiene la corona y la palma también de color dorado, simbolos de la victoria (Fig. 23). La escena está realizada para ser vista desde el lado $N$. de la habitación, es decir, dando la espalda al oecus-triclinium. Su acusado simbolismo ha dado lugar a diversas interpretaciones. M. Bairrão Oleiro considera que la composición tiene un determinado carácter religioso y filosófico por la asociación de la caza con las Estaciones y el auriga victorioso: la caza, símbolo del triunfo de la virtus sobre la muerte, unida a las Estaciones que simbolizan la renovación y resurrección, llevan lógicamente al auriga victorioso corriendo en un cielo azul, como 


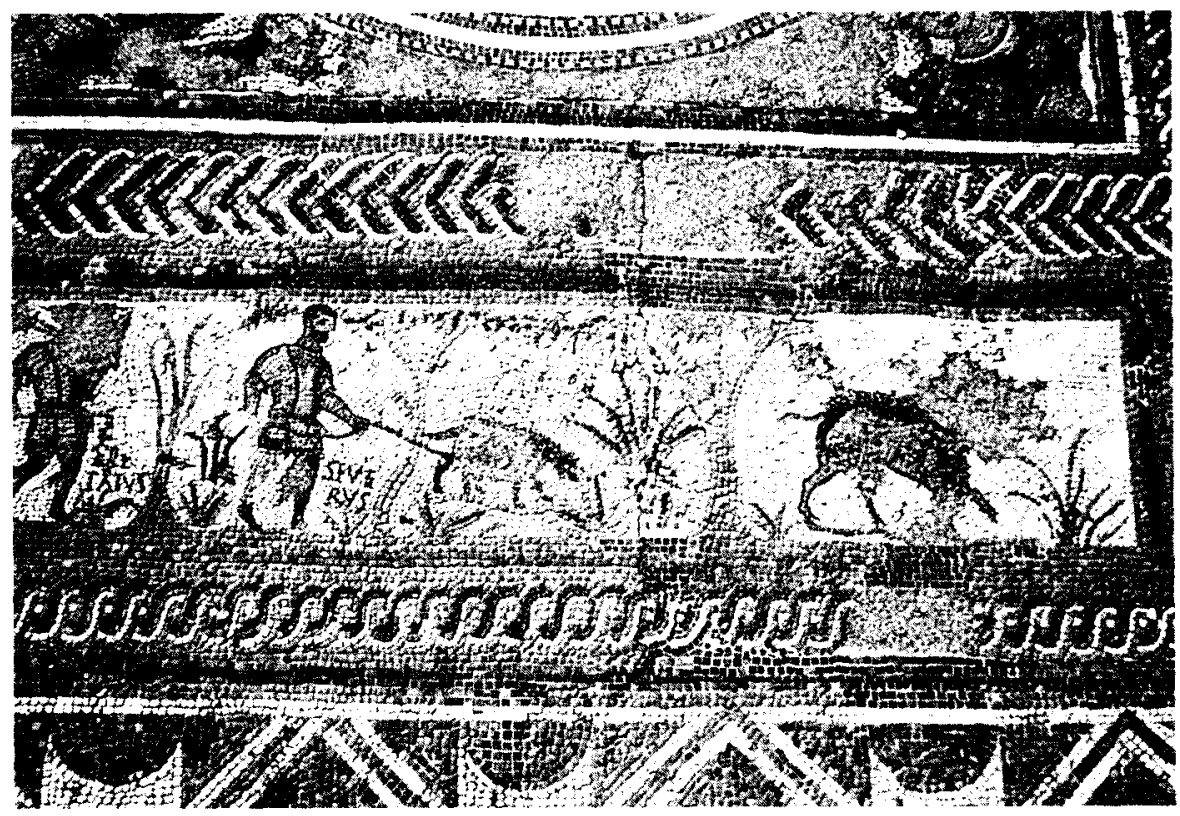

Fig. 17 Mosaico del Auriga. Escena de caza. (Foto G. L. M.).

imagen del encuentro del alma del justo y las divinidades astrales ${ }^{36}$. $F$. Camargo e Almeida identifica a la figura del Auriga con el Sol, tesis insostenible por la ausencia del nimbo o de la corona radiada, como acertadamente señala K. M. D. Dunbabin ${ }^{37}$. De acuerdo con esta autora podria tratarse de la constelación del Auriga y en este sentido, como he intentado demostrar en otra parte, es posible establecer su relación con Hippólito quien, según Pausanias (II 32,1), fue arrebatado al cielo por favor divino y convertido en la constelación del Auriga. El joven cazador de Trezena sirve, de esta forma, de nexo entre la naturaleza cuya riqueza se renueva con el paso de las estaciones y el elemento cósmico

36 Bairráo Oleiro, op. cit. (n. 4). 262.

${ }^{37}$ Camargo e Almeida, F., “Considerações sobre o mosaico das quatro estações de Conimbriga. A represetação do Sol", Actas do /l Congreso Nacional de Arqueologia, Coimbra 1971, 495 ss.; DUNBABIN, K. M. D., "The Victorious Charioteer on Mosaics and Related Monuments", $A J A$ 86, 1982, 84-85, que igualmente rechaza la identificación con un auriga del circo por no llevar la indumentaria típica de éstos. 


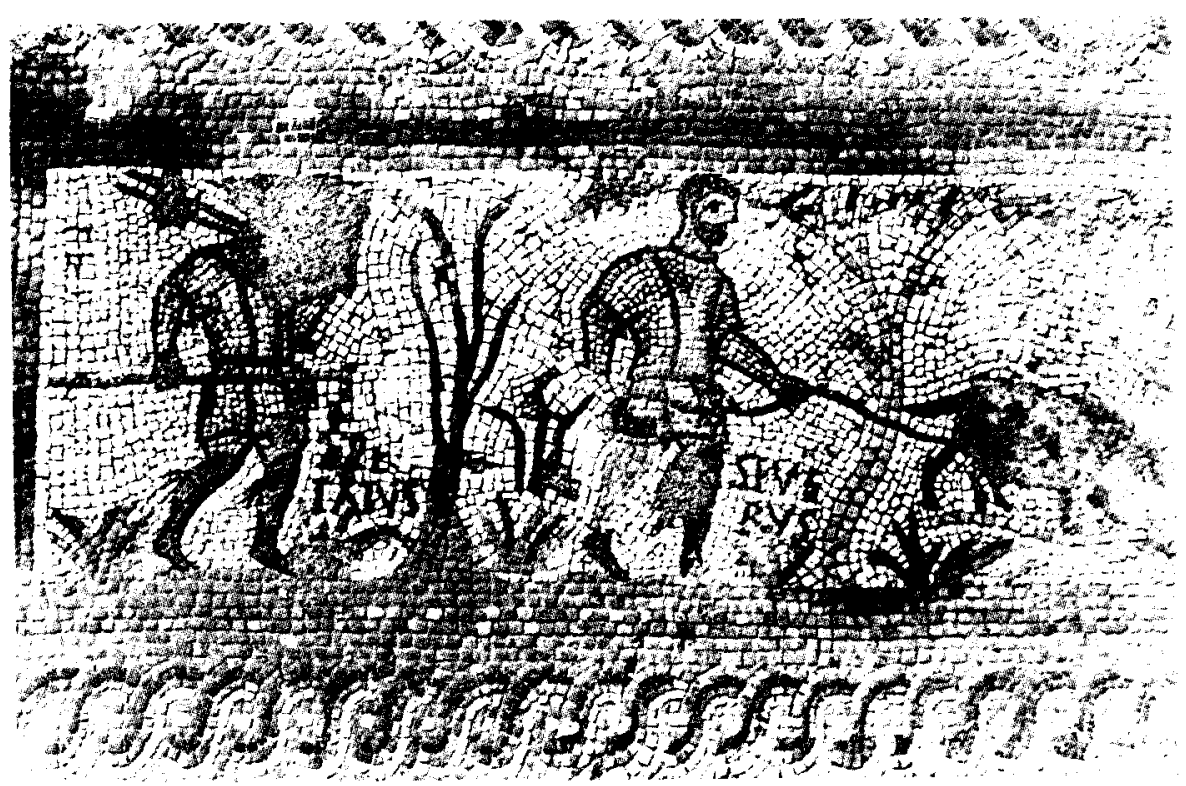

Fig. 18 Mosaico del Auriga. Escena de caza. (Foto G. L. M.).

que ordena esta renovación, como símbolo de la resurrección y de la inmortalidad que le proporciona su virtus ${ }^{38}$.

Una puerta situada en la pared $\mathrm{N}$. de esta habitación da acceso a otra estancia algo mayor, de $6 \times 7,2 \mathrm{~m}$, pavimentada con un mosaico bicolor de triángulos curvilíneos cuyo emblema, de forma circular, va decorado con una curiosa representación de tema animalístico (Fig. 24). Junto a un árbol de ramas grises y verde follaje aparecen dos animales de perfil, que se interpretan como un elefante y un camello ${ }^{39}$. Aquel, cuyas extremidades no dejan lugar a dudas en cuanto a su identificación como un paquidermo, está representado de pie, dirigiendo su trompa hacia el árbol. El cuerpo es de color gris y los colmillos ocres. En el plano superior aparece sentado de perfil otro animal, de color ocre, cuya joroba le identifica con un camello. Es posible que el simbolismo de esta representación esté relacionado con el carácter herbíboro de ambos ani-

${ }^{38}$ Lopez Monteagudo, G., "El mosaico del Auriga de Conimbriga. Ensayo de interpretación". Homenaje al Prof. J. M. Blázquez, (en prensa).

${ }^{39}$ MaC Millan, Ch., Mosaíques romaines du Portugal, Paris 1986, 28. 


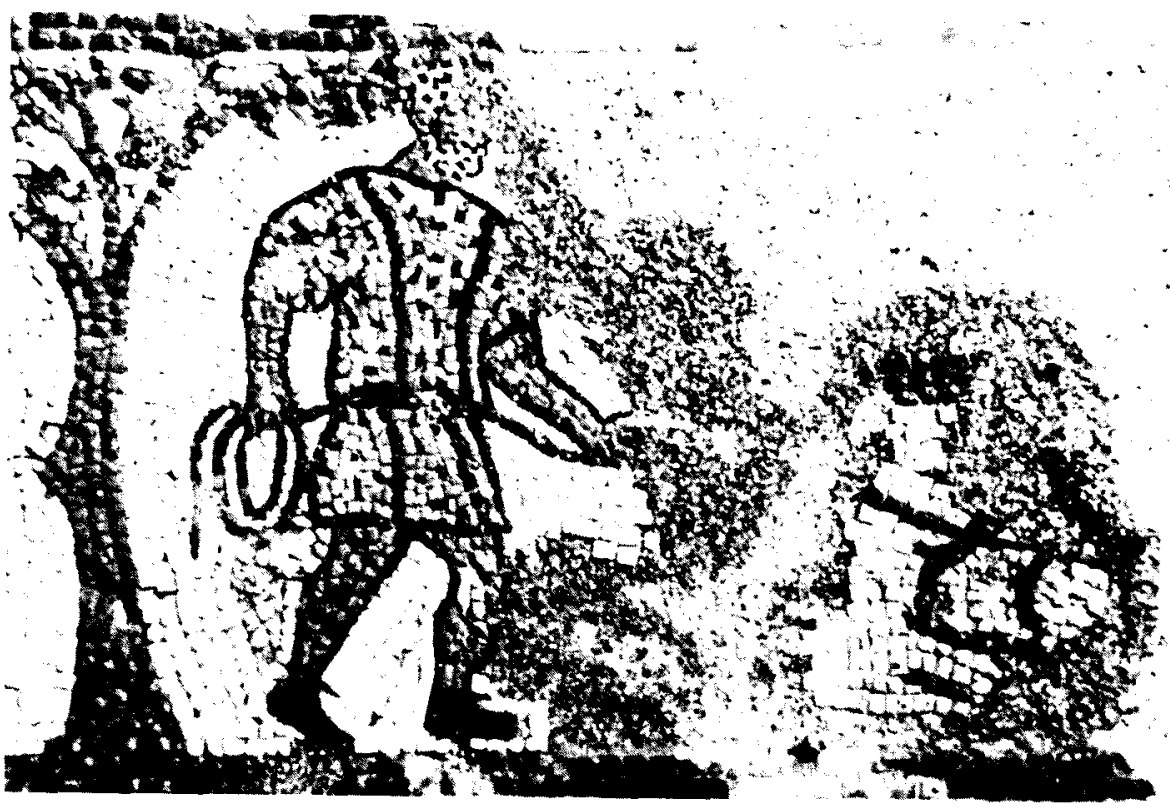

Fig. 19 Mosaico del Auriga. Escena de caza. (Foto G. L. M.).

males, lo que le proporciona una cierta «bondad" frente a los carnivoros. O quizás se han escogido por ser animales que forman parte del thiasos báquico: un elefante y un camello aparecen entre los animales representados en el mosaico dionisiaco de la Casa de Sileno de El Djem, ca. 260$280^{40}$.

Lo muros $E$. y $O$. de esta habitación presentan dos vanos, accediéndose a través del situado en la pared $E$. a un pequeño peristilo con fuente central, del que queda un emblema de forma cuadrada con escena de caza, muy similar al descrito del peristilo principal: el cazador, vestido con túnica corta de color gris, adornada con clavi ocres, y calzando fasciae crurales, camina de perfil hacia la izquierda llevando en la mano de este lado un jabato y en la derecha un cesto. No hay indicación de paisaje ni de sombras (Fig. 25).

40 Dunbabin, K. M. D., op cit. (n. 8), 180-181, PI. 106. El tipo iconográfico aparece en dos lucernas africanas del siglo । d. C. (cf. Deneauve, J., Lampes de Carthage, Paris 1969, núms. 504 y 505). 


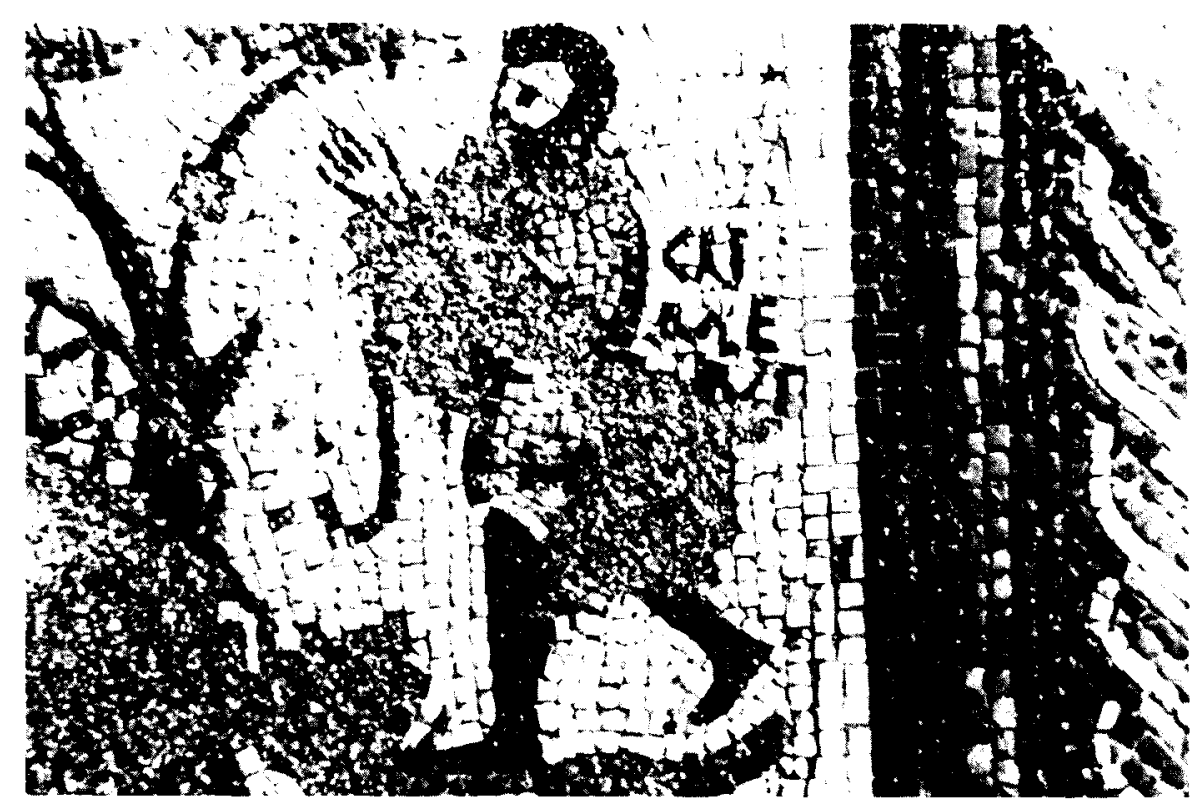

Fig. 20 Mosaico del Auriga. Escena de caza. (Foto G. L. M.).

Desde el ángulo S.-SO. del gran peristilo se accede a otra zona de la casa integrada por cuatro habitaciones, identificadas como dormitorios, que se disponen alrededor de otro peristilo más pequeño. Dos de ellas van pavimentadas con mosaicos de tipo geométrico y las otras dos con escenas figuradas. La más grande, que mide $6 \times 7,2 \mathrm{~m}$, presenta una decoración parietal formada por pilastras de estuco y se cubre con un bello mosaico figurado (Fig. 26). El emblema, de forma cuadrada, aparece rodeado por una rica decoración geométrica de diferentes motivos en cada uno de los lados. El esquema es similar al del mosaico del Auriga: franja rectangular enmarcando un cuadrado, en donde se inscribe un círculo, en el que se representa una escena cinegética. La banda rectangular va decorada con una serie de roleos de hojas de acanto y cuatro cráteras en los ángulos. El cuadrado, enmarcado por un sogueado de dos cabos en ocre y blanco sobre fondo gris-azulado, ofrece en los cuatro espacios triangulares que resultan de la inserción del circulo central cuatro aves zancudas entre roleos vegetales con hojas lanceoladas (hederae). Otro sogueado en los mismos tonos que el anterior delimita el medallón central, en donde se desarrolla una escena de cacería de ciervos en un paisaje integrado por árboles y matorrales muy estilizados. Se 


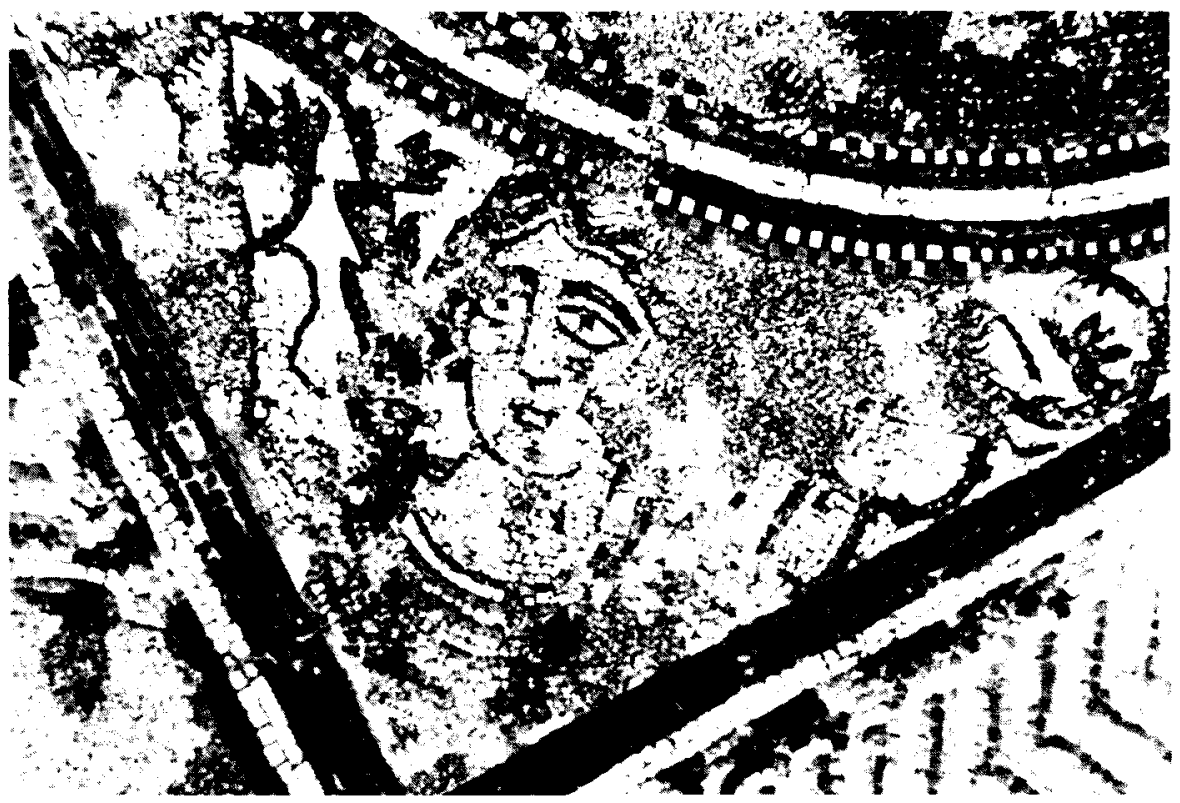

Fig. 21. Mosaico del auriga. Figura alegorica. (Foto G. L. M.).

trata de una caza de tipo realista de un venado y una cierva, en la que intervienen cuatro jinetes y dos perros. Los cazadores, que montan briosos corceles adornados con arneses, visten túnica de mangas cortas por encima de las rodillas, de color amarillo-ocre adornada con clavi y calzan fasciae crurales. Dos de ellos llevan lanza o venablo en la mano derecha (Fig. 27), mientras que los otros dos blanden una especie de látigo (Fig. 28 ), con paralelos en otros cazadores a caballo de los mosaicos tunecinos de Althiburos, ca. 280-290 ${ }^{41}$, y de la Pequeña caza de la Casa de los Laberii en Oudna, datado a fines del siglo 11 o a comienzos del siguiente ${ }^{42}$. Aunque en la escena pueden identificarse con claridad dos grupos, integrado cada uno por un jinete con lanza, otro con látigo y un perro acosando a un venado en un caso y a una cierva en otro, la sensación que produce este cuadro es la de un gran movimiento giratorio siempre en un mismo sentido, quizás por desarrollarse dentro de un esquema circular. Esta características de movimiento continuo, unida al nú-

4" ENNAÏFER, M., op cit. (n. 15), pl. CXXVII y CXXXVIII.

42 Dunbabin, K. M. D., (n. 8), PI. 44. 


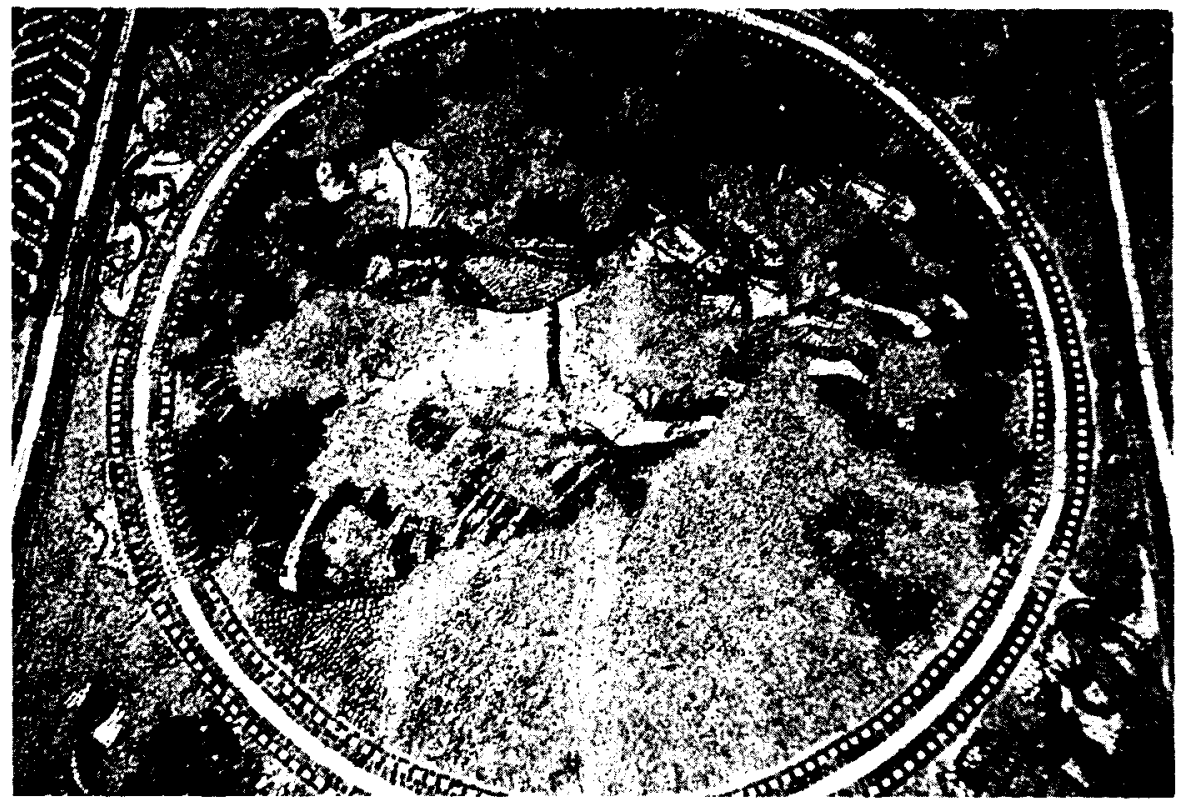

Fig. 22. Mosaico del Auriga. Emblema central. (Foto G. L. M.).

mero de los cazadores participantes que son cuatro, tal vez tiene alguna conexión con el paso de las estaciones. Si bien las excavaciones proporcionan una cronologia en época severiana, este mosaico de la Casa de los Surtidores de Conimbriga por la representación ilusionista del paisaje, como acertadamente señaló $\mathrm{A}$. Balil, se adelanta a las corrientes artísticas del Bajo Imperio, de carácter impresionista, que se detectan en los mosaicos hispanos de caza de Baños Valdearados, Campo de Villavidel y de Dulcitius de El Ramalete ${ }^{43}$.

El último pavimento con escena figurada, en esta ocasión de tema mitológico, de la Casa de los Surtidores cubre el cubiculum situado al otro lado de este peristilo, casi en oposición al acabado de comentar. El mosaico, de $3 \times 3 \mathrm{~m}$, ofrece una rica y variada decoración de tipo geométrico con un emblema descentrado de forma cuadrada. Una ancha franja, decorada con motivos fitomorfos en tonos ocres, enmarca el cua-

${ }^{43}$ BaLIL, A., "Algunos mosaicos hispanoromanos de época tardia", Princ. Viana XXVI, 1965, 287-288; BLAZQUEZ, J. M., "Arte y sociedad en los mosaicos romanos de Navarra", I Congreso General de Historia de Navarra, Pamplona 1987, 320 ss. 


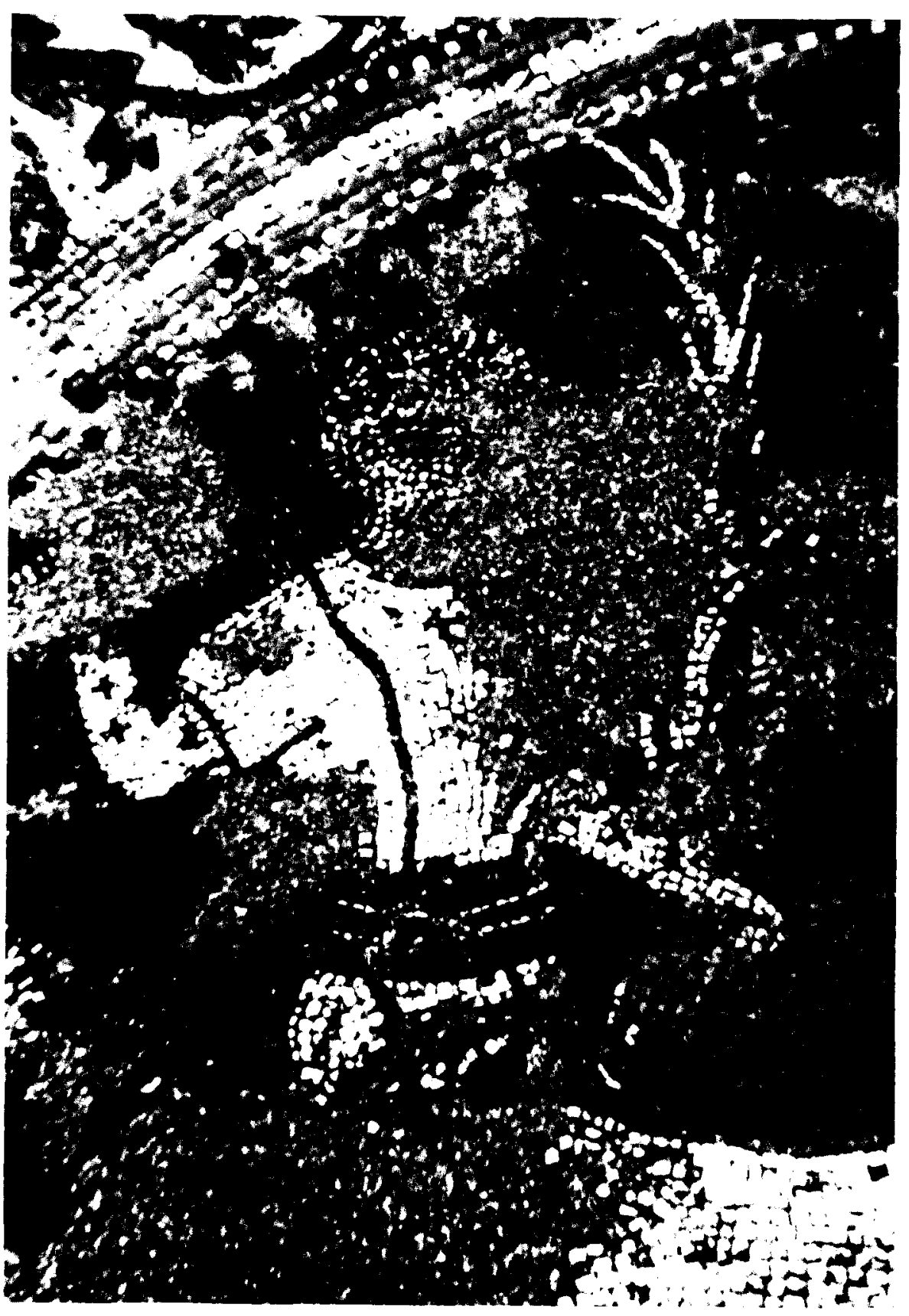

Fig. 23. Mosaico del Auriga. Detalle del emblema central. (Foto G. L. M.). 


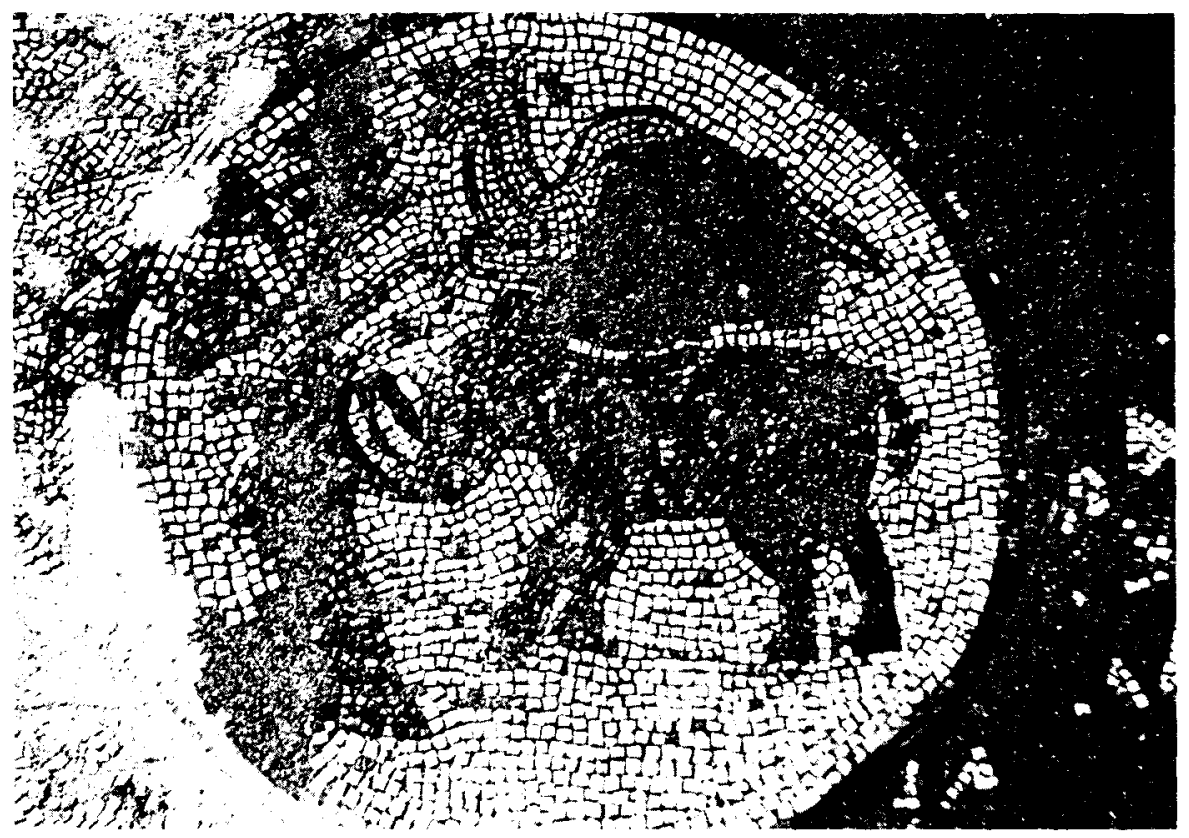

Fig. 24. Mosaico con representación animalistica. (Foto G. L. M.).

drado en donde se inscribe un octógono con la representación de Sileno montado sobre el asno y conducido por un sátiro (Fig. 29). Ambos personajes visten túnica de manga corta por encima de la rodilla, de color amarillo-ocre adornada con clavi de tono más oscuro y caminan, al parecer descalzos, hacia la derecha en un paisaje de matorrales. Unas lineas bajo las figuras indican las sombras. Sileno. representado como un hombre viejo, porta el tirso en la mano izquierda, mientras que el sátiro, joven de cabello oscuro, tira de las riendas con la mano izquierda y sostiene el pedum en la derecha. En la parte alta de la escena cuelga la siringa, de forma similar al cuerno del mosaico de Perseo y la Medusa que decora el peristilo principal. Hispania ha dado otras representaciones de Sileno montado sobre el asno en los mosaicos báquicos de Itálica, Mérida y Liédana, fechados de los siglos III al $v^{44}$.

${ }_{44}$ Blanco, A., Mosaico romanos de Itálica, Madrid 1978, 29 ss., láms. 15-16; BLAzquez, J. M., "Mosaicos báquicos en la Península Ibérica", AEspA 57, 1984, 74 y 80, figs. 6 y 26; Alvarez Martínez, J. M., op. cit. (n. 10), 42 ss., lám. 19; Fernandez-Galiano, D., Mosaicos Romanos del Convento Caesaraugustano, Zaragoza 1987, 118, lám. LVIII. 


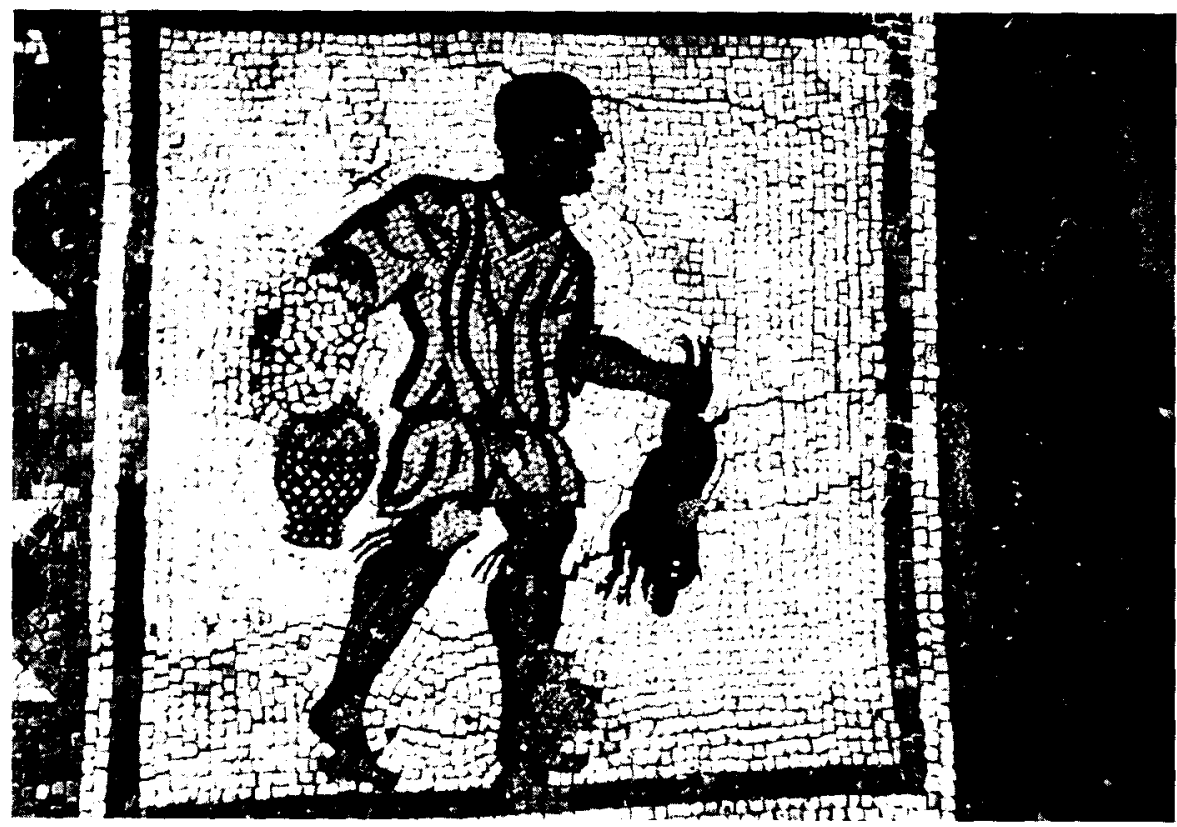

Fig. 25. Mosaico del cazador. (Foto G. L. M.).

El análisis de los mosaicos figurados de la Casa de los Surtidores de Conimbriga revela la existencia de una unidad de composición y de estilo. Efectivamente, hay un predominio de los esquemas circulares y una repetición de las figuras geométricas y de los motivos decorativos tanto vegetales como figurados. Lo mismo puede decirse acerca de los colores utilizados, en donde se observa una preponderancia de la gama de los ocres y de los grises. Idénticos los recursos empleados para representar el paisaje o las sombras. El mismo tipo iconográfico al que responden la mayoria de los personajes que intervienen en las distintas escenas. Pero esta unidad no se reduce solo a los aspectos formales, sino que se extiende también al contenido de las representaciones y a la forma de estar tratadas. Existe una tendencia a la simplificación y al uso de pseudoemblemata en las escenas mitológicas, procediéndose por alusiones al escogerse uno solo de los varios episodios que componen el mito, como ocurre en los mosaicos de Perseo y de Acteón. Otras veces se recurre a figuras simbólicas de fuerte contenido alusivo, como ocurre con el mosaico del Laberinto o del centauro marino, o los emblemas de Sileno y del elefante y el camello que suponen una expresión reducida o simplificada del thiasos báquico. W. A. Daszewski, al referirse a las re- 


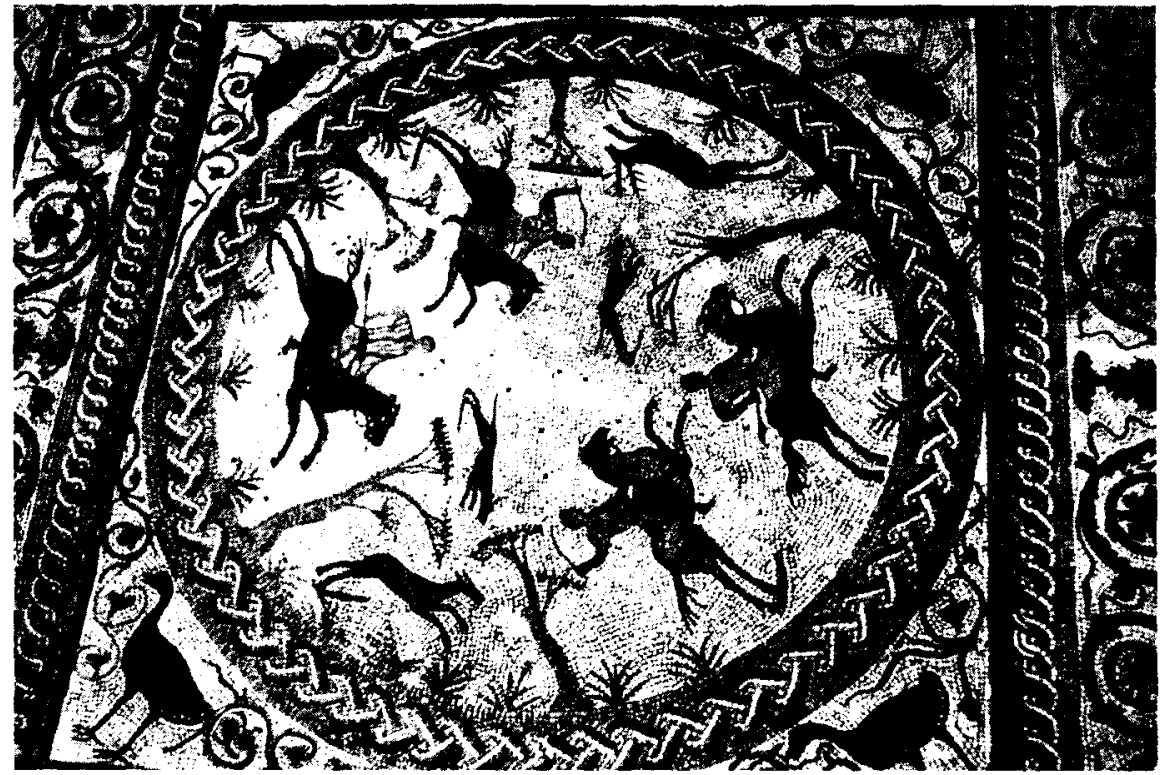

Fig. 26. Mosaico de caceria a caballo. (Foto G. L. M.).

presentaciones simplificadas del mito de Teseo y el Minotauro, afirma que estas escenas informan de manera extremadamente concisa pero al mismo tiempo llena de contenido, convirtiéndose el mosaico en un catalizador de imágenes y de sensaciones creadas en la imaginación y en el espíritu del espectador que conoce el mito; de esta forma, el cuadro sirve para estimular la imaginación al sugerir los acontecimientos sin contarlos ${ }^{45}$. Es una interpretación que puede aplicarse perfectamente a todos los emblemas figurados de la Casa de los Surtidores de Conimbriga.

La temática de estos pavimentos no se ha escogido al azar, muy por el contrario ha sido cuidadosamente seleccionada por el propietario de la casa con un sentido filosófico de resaltar la ldea de victoria y de virtud moral. Asi, los episodios mitológicos de Perseo, vencedor de la Medusa y el monstruo marino, y de Bellerofonte dando muerte a la Quimera constituyen un símbolo del triunfo de la pietas, frente al castigo representado

45 DASZEWSKI, W. A., op. cit. (n. 5), $90 \mathrm{ss}$. 


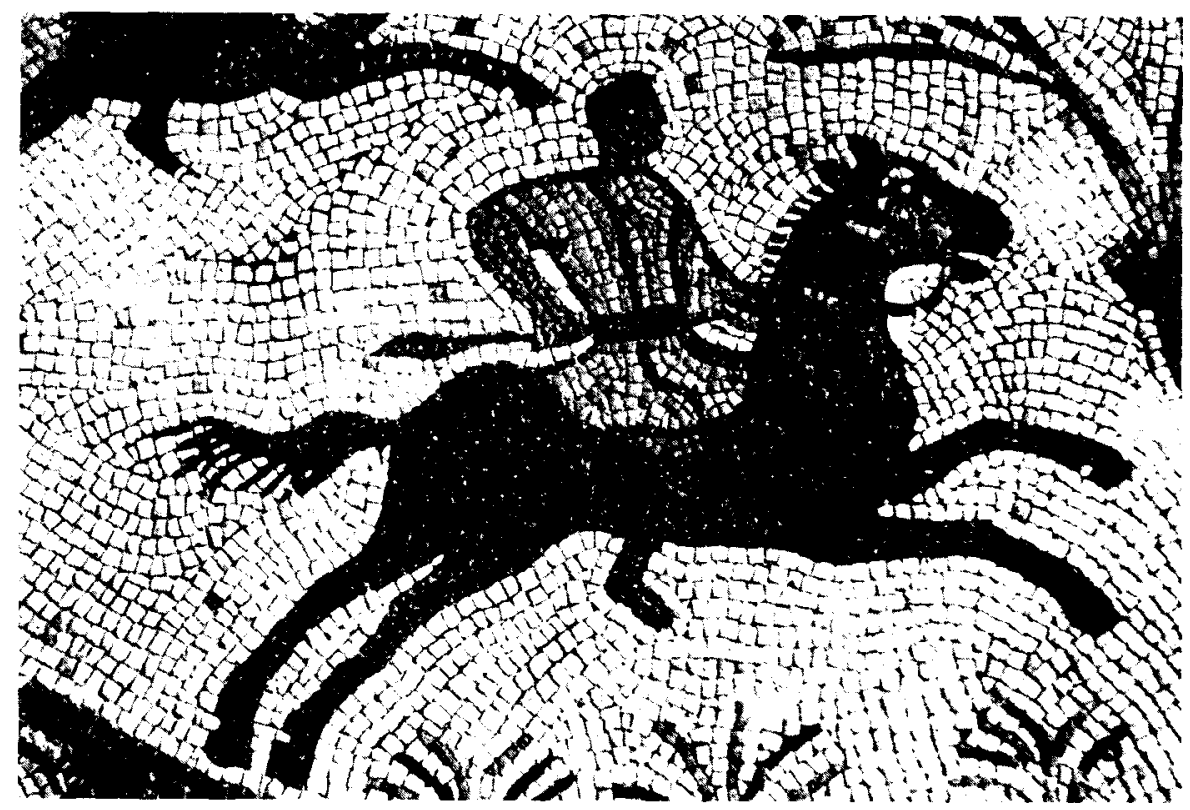

Fig. 27. Detalle del mosaico de caceria a caballo. (Foto G. L. M.)

por Acteón devorado por sus perros. Las imágenes relacionadas con los misterios báquicos, Sileno sobre el asno conducido por el sátiro, elefante y camello, cráteras y aves, cabras y panteras, e incluso el centauro marino que a veces forma parte del cortejo dionisiaco como en el mosaico de las Termas de Trajano en Acholla ${ }^{46}$, aluden a la idea de inmortalidad a la que se accede por el ejercicio de la virtud moral. Las escenas de caza simbolizan el triundo de la virtus sobre la muerte y con este sentido pasan a decorar los sarcófagos y se utilizan en contextos funerarios. Su asociación con las imágenes de las Estaciones contiene un significado de resurrección o, lo que es lo mismo, de inmortalidad representada por la figura del auriga, punto culminante del discurso iconográfico de la Casa de los Surtidores, como imagen perfecta de la virtud moral que proporciona la inmortalidad al alma. Pero el ejercicio de la pietas se halla constantemente amenazado por el Invidus y para conjurarlo se utilizan una serie de símbolos mágicos como son los tridentes, los delfines, peces y

46 Foucher, L., La Maison de la Procéssion Dionisiaque à El Djem, Paris 1963, fig. 4; TORRES, M., op. cit. (n. 19), 111-112. 


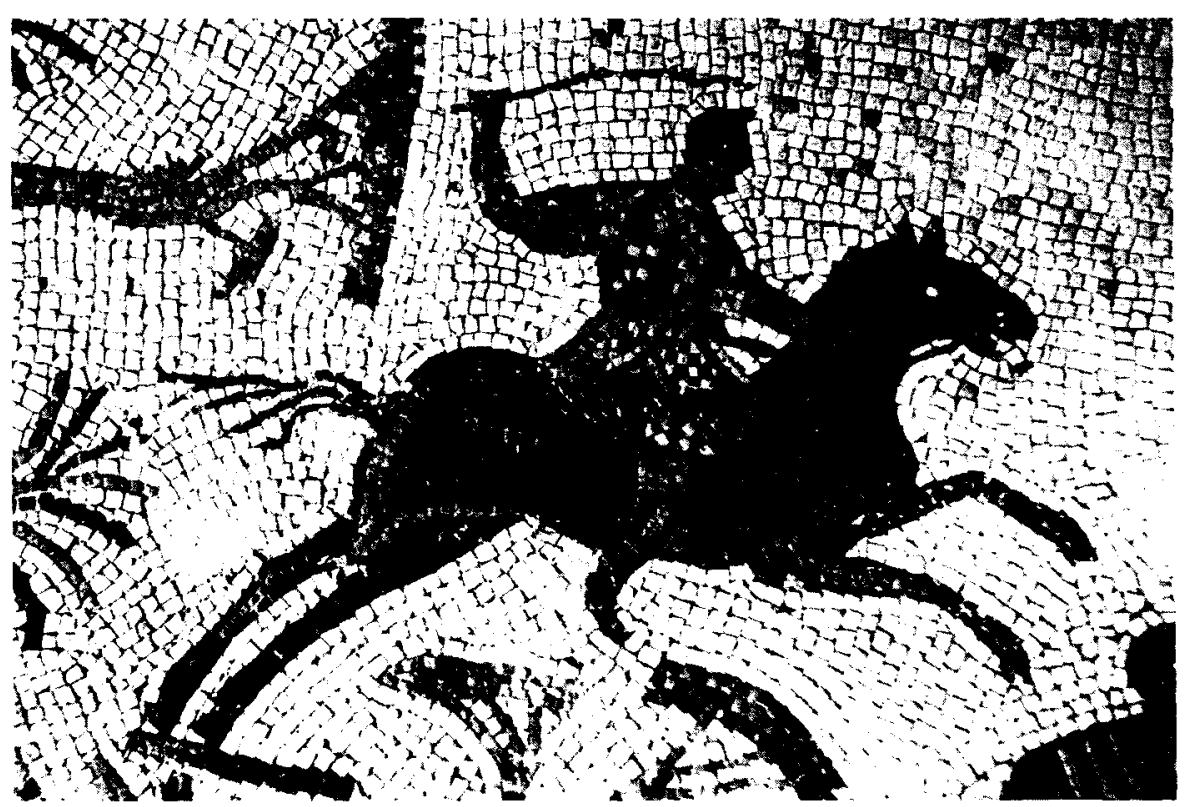

Fig. 28. Detalle del mosaico de caceria a caballo. (Foto G. L. M.).

pequeños monstruos marinos, pájaros y kantharoi, hederae, que por su carácter benéfico y apotropaico sirven para alejar la influencia del Mal ${ }^{47}$. Con esta misma idea se ha colocado la imagen del Laberinto a la entrada de la vivienda ya que, como símbolo del mundo subterráneo, sirve de protección a la casa y a sus habitantes contra los maleficios alejando la amenaza de muerte ${ }^{48}$.

En resumen, puede decirse que el propietario de la Casa de los Surtidores de Conimbriga tenía un buen conocimiento de la mitología y de las corrientes filosóficas $y$, de esta manera, ha podido ejercer un control directo sobre el contenido de las escenas figuradas en sus pavimentos.

En cuanto a la cronología severiana que se viene manteniendo para estos mosaicos en base a los datos proporcionados por las excavacio-

47 Algunos de estos simbolos aparecen en el mosaico que cubre una piscina de Volubilis (cf. Thouvenot, R., "Mosaïques à motifs prophylactiques en Maurétanie Tingitane", Actes du 79 Congrès National des Societés Savantes, París 1957, 187 ss.).

4 DASZEWSKI, W. A., op. cit. (n. 5), 95. 


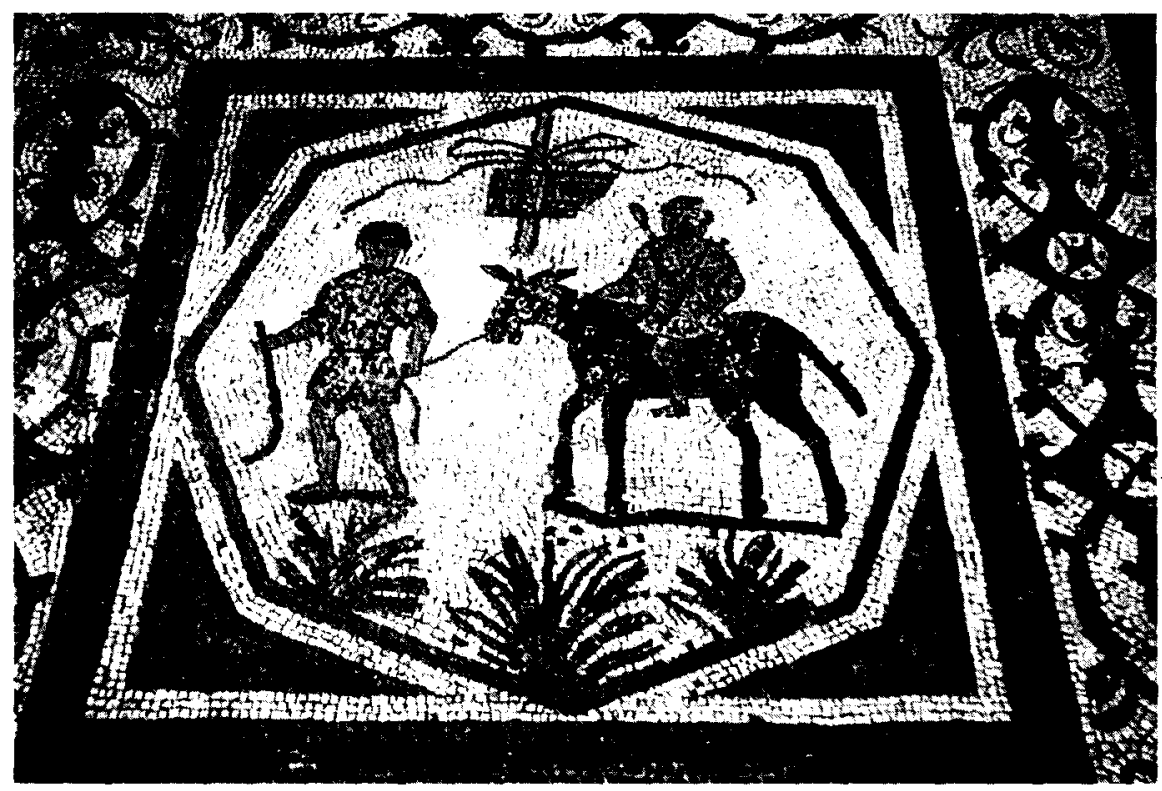

Fig. 29. Mosaico de Sileno y el asno. (Foto G. L. M.).

nes, ya $M$. Bairrão apuntaba en 1965 que "les travaux récents de consolidation des mosaïques ont permi de trouver. au-dessous d'eux, des traces de transformation de la maison. Cette transformation a dû être contemporaine de la posse d'une grande partie, si ce n'est de la totalité des mosaïques" "49. Por otra parte, tanto los paralelos apuntados como su estilo impresionista les acercan a una cronologia más baja. Quede, sin embargo, este punto pendiente de nuevos datos que permitan su precisa datación.

49 Bairráo Oleiro, op. cit. (n. 4), 263. 